\title{
Article \\ Nanostructured Molybdenum-Oxide Anodes for Lithium-Ion Batteries: An Outstanding Increase in Capacity
}

\author{
Hua Wang ${ }^{1}$, Tianyi Li ${ }^{1}\left(\mathbb{D}\right.$, Ahmed M. Hashem ${ }^{2, *}$, Ashraf E. Abdel-Ghany ${ }^{2}$ (D) Rasha S. El-Tawil ${ }^{2}$, Hanaa \\ M. Abuzeid ${ }^{2} \mathbb{D}$, Amanda Coughlin ${ }^{3}$, Kai Chang ${ }^{1}$, Shixiong Zhang ${ }^{3}$, Hazim El-Mounayri ${ }^{1}$, Andres Tovar ${ }^{1} \mathbb{D}$, \\ Likun Zhu ${ }^{1, *}$ and Christian M. Julien ${ }^{4, *}$ D
}

1 Department of Mechanical and Energy Engineering, Indiana University-Purdue University Indianapolis, Indianapolis, IN 46202, USA; wanghua@iu.edu (H.W.); t141@iupui.edu (T.L.); kc59@iu.edu (K.C.); helmouna@iupui.edu (H.E.-M.); tovara@iupui.edu (A.T.)

2 National Research Centre, Inorganic Chemistry Department, Behoes Street, Dokki, Giza 12622, Egypt; achraf_28@yahoo.com (A.E.A.-G.); r2samir@yahoo.com (R.S.E.-T.); hanaa20619@hotmail.com (H.M.A.)

3 Department of Physics, Indiana University, Bloomington, IN 47405, USA; amacough@iu.edu (A.C.); sxzhang@indiana.edu (S.Z.)

4 Institut de Minéralogie, de Physique des Matériaux et Cosmologie (IMPMC), Sorbonne Université, UMR-CNRS 7590, 4 Place Jussieu, 75752 Paris, France

* Correspondence: ahmedh242@yahoo.com (A.M.H.); likzhu@iupui.edu (L.Z.); christian.julien@sorbonne-universite.fr (C.M.J.)

\section{check for}

updates

Citation: Wang, H.; Li, T.; Hashem, A.M.; Abdel-Ghany, A.E.; El-Tawil, R.S.; Abuzeid, H.M.; Coughlin, A.; Chang, K.; Zhang, S.; El-Mounayri, H.; et al. Nanostructured Molybdenum-Oxide Anodes for Lithium-Ion Batteries: An Outstanding Increase in Capacity. Nanomaterials 2021, 12, 13. https:// doi.org/10.3390/nano12010013

Academic Editor: Henrich Frielinghaus

Received: 6 December 2021 Accepted: 17 December 2021 Published: 21 December 2021

Publisher's Note: MDPI stays neutral with regard to jurisdictional claims in published maps and institutional affiliations.

Copyright: () 2021 by the authors. Licensee MDPI, Basel, Switzerland. This article is an open access article distributed under the terms and conditions of the Creative Commons Attribution (CC BY) license (https:/ / creativecommons.org/licenses/by/ $4.0 /)$.

\begin{abstract}
This work aimed at synthesizing $\mathrm{MoO}_{3}$ and $\mathrm{MoO}_{2}$ by a facile and cost-effective method using extract of orange peel as a biological chelating and reducing agent for ammonium molybdate. Calcination of the precursor in air at $450{ }^{\circ} \mathrm{C}$ yielded the stochiometric $\mathrm{MoO}_{3}$ phase, while calcination in vacuum produced the reduced form $\mathrm{MoO}_{2}$ as evidenced by X-ray powder diffraction, Raman scattering spectroscopy, and X-ray photoelectron spectroscopy results. Scanning and transmission electron microscopy images showed different morphologies and sizes of $\mathrm{MoO}_{\mathbf{x}}$ particles. $\mathrm{MoO}_{3}$ formed platelet particles that were larger than those observed for $\mathrm{MoO}_{2} . \mathrm{MoO}_{3}$ showed stable thermal behavior until approximately $800{ }^{\circ} \mathrm{C}$, whereas $\mathrm{MoO}_{2}$ showed weight gain at approximately $400{ }^{\circ} \mathrm{C}$ due to the fact of re-oxidation and oxygen uptake and, hence, conversion to stoichiometric $\mathrm{MoO}_{3}$. Electrochemically, traditional performance was observed for $\mathrm{MoO}_{3}$, which exhibited a high initial capacity with steady and continuous capacity fading upon cycling. On the contrary, $\mathrm{MoO}_{2}$ showed completely different electrochemical behavior with less initial capacity but an outstanding increase in capacity upon cycling, which reached $1600 \mathrm{mAh} \mathrm{g}^{-1}$ after 800 cycles. This outstanding electrochemical performance of $\mathrm{MoO}_{2}$ may be attributed to its higher surface area and better electrical conductivity as observed in surface area and impedance investigations.
\end{abstract}

Keywords: molybdenum oxides; green synthesis; biological chelator; additional capacity; anodes; lithium-ion batteries

\section{Introduction}

Understanding and realization of the benefit of efficient energy storage is one of the most important strategies for achieving sustainable development [1,2]. Nowadays, lithiumion batteries (LIBs) have become one of the most important energy storage technologies due to the fact of their higher storage capacity and power density compared to other rechargeable batteries [3-5]. The development and rapid increase in portable electronic devices and electric vehicles have accelerated the pursuit of developing LIBs with high energy and power densities [6,7]. Therefore, it is essential to develop high-capacity electrode materials for LIBs [8-13]. Graphite has become the standard anode material for LIBs since their commercialization by Sony Corporation [14]. However, graphite has relatively low theoretical capacity $\left(372 \mathrm{mAh} \mathrm{g}^{-1}\right.$ and $850 \mathrm{mAh} \mathrm{cm}^{-3}$ ), which cannot meet the demand of current large-scale energy applications [15]. To address this issue, there is a continuous 
effort to explore alternative anode materials. For instance, transition metal oxides (TMOs), such as $\mathrm{NiO}, \mathrm{MnO}_{2}, \mathrm{TiO}_{2}, \mathrm{Fe}_{3} \mathrm{O}_{4}, \mathrm{MoO}_{3}$, and $\mathrm{MoO}_{2}$, have been studied as anode materials for LIBs. These oxides are abundant, low cost, and have a high theoretical specific capacity of approximately 500-1200 $\mathrm{mAh}^{-1}$ due to the fact of their conversion reaction upon lithiation [16-21].

Molybdenum oxides with different oxidation states (e.g., $\mathrm{MoO}_{3}, \mathrm{MoO}_{3-\delta}, \mathrm{Mo}_{\mathrm{n}} \mathrm{O}_{3 \mathrm{n}-1}$, and $\mathrm{MoO}_{2}$ ) and a broad spectrum of electrical properties ranging from wide band gap semiconducting $\left(\mathrm{MoO}_{3}\right)$ to metallic $\left(\mathrm{MoO}_{2}\right)$ character are considered as promising anode materials for LIBs [22]. Their specific capacities are significantly higher than that of graphite [23-29]. In particular, $\mathrm{MoO}_{3}$ with an orthorhombic crystal structure is a thermal stable, abundant, cost effective, and a rather safe oxide with a theoretical capacity of $1117 \mathrm{mAh} \mathrm{g}^{-1}$ and a typical discharge potential plateau around $0.45 \mathrm{~V} \mathrm{[30-34].} \mathrm{It} \mathrm{has} \mathrm{a}$ unique layered structure that is convenient for fast lithium diffusion transport [15,35-38]. The overall first lithiation reaction for $\mathrm{MoO}_{3}$ is described by two reactions: the lithium insertion (addition) at a potential $>1.5 \mathrm{~V}$ up to $x \approx 1.2$ (Equation (1)) and the conversion (transformation) reaction at a potential $<0.5 \mathrm{~V}$ up to $x \approx 6.0$ (Equation (2)) as follows [22]:

$$
\begin{gathered}
\mathrm{MoO}_{3}+x \mathrm{Li}^{+}+x \mathrm{e}^{-} \rightarrow \mathrm{Li}_{x} \mathrm{MoO}_{3} \\
\mathrm{Li}_{x} \mathrm{MoO}_{3}+(6-x) \mathrm{Li}^{+}+(6-x) \mathrm{e}^{-} \rightarrow \mathrm{Mo}+3 \mathrm{Li}_{2} \mathrm{O} .
\end{gathered}
$$

Some drawbacks have been reported for $\mathrm{MoO}_{3}$, such as phase transformation accompanied by volume expansion with repeating cycling, which leads to a rapid capacity fading $[39,40]$.

On the other hand, $\mathrm{MoO}_{2}$ crystallizes in the monoclinic structure with space group $P 2_{1} / c$, which can be viewed as a distorted rutile phase. This structure is composed of $\mathrm{MoO}_{6}$ octahedra joined by edge-sharing, which form a $(1 \times 1)$-tunneling network [41,42]. In addition, $\mathrm{MoO}_{2}$ has outstanding properties for energy storage applications, e.g., metal-like conductivity $\left(\sim 6 \times 10^{3} \mathrm{~S} \mathrm{~cm}^{-1}\right)$, very low toxicity, cost-effectiveness, high chemical and thermal stability, high volumetric capacity due to the fact of its high density $\left(6.5 \mathrm{~g} \mathrm{~cm}^{-3}\right)$, and high theoretical capacity $\left(838 \mathrm{mAh}^{-1}\right)$ [43-45]. The first lithiation mechanism is an insertion-type reaction that takes place in the bulk and amorphous $\mathrm{MoO}_{2}$ electrodes with only one-electron reduction as described by Equation (3) [46]:

$$
\mathrm{MoO}_{2}+x \mathrm{Li}^{+}+x \mathrm{e}^{-} \leftrightarrow \mathrm{Li}_{x} \mathrm{MoO}_{2}
$$

with $0 \leq x \leq 0.98$. The second mechanism is a conversion reaction that gradually resolves $\mathrm{Li}_{\mathrm{x}} \mathrm{MoO}_{2}$ as described by Equation (4) [47]:

$$
\mathrm{Li}_{x} \mathrm{MoO}_{2}+(4-x) \mathrm{Li} \leftrightarrow 2 \mathrm{Li}_{2} \mathrm{O}+\mathrm{Mo}
$$

that shows the formation of metallic Mo and $\mathrm{Li}_{2} \mathrm{O}$.

$\mathrm{MoO}_{3}$ and $\mathrm{MoO}_{2}$ have been prepared in different morphologies, e.g., nanoparticles [48], nanowires [49,50], nanorods [51,52], nanotubes [53], nanosheets [54], and nanobelts [55]. These nanosized fabrications were expected to improve the electrochemical performance [56]. However, these fabrication methods are complicated, expensive, energy- and time-consuming, and non-scalable [57]. To alleviate these limitations, to some extent, an attempt was made to use a rather benign approach via simple, green, and eco-friendly reducing agents for nanoparticles formation [58]. Green synthesized particles have low toxicity and are more stable than those prepared by traditional methods, as biological sources provide a stabilizing and capping effect for the synthesized particles, especially extracts of plants [58].

Extracts of waste products have been used as cost-effective, eco-friendly, and efficient raw materials for various energy storage applications $[59,60]$. In our previous work, we used extracts of lemon and orange peels to synthesize manganese dioxides, which has been used as cathode materials in LIBs and supercapacitors $[60,61]$. Further processing and using large quantities of orange peels as a byproduct will reduce hazardous impacts and 
serious environmental pollution [60]. Orange peels contain polyphenolic and flavonoid compounds which have hesperidin, narirutin, naringin, and eriocitrin [62]. It is well known that the phenolic compounds have at least one aromatic ring. The latter is attached to one or more hydroxyl groups. The number and position of the carboxylic group has a direct impact on reducing the antioxidant ability of flavonoids and phenolic acids. As the number of hydroxyl group increases, the antioxidant activity increases [63]. Orange is considered as one of the most important fruits with a global production of $48.8(2016 / 17)$ million tons. Industrial extraction of citrus juice consumed a large portion of this production. As a result of this industry, there are large amounts of residues, e.g., peel and segment membranes. A high percent of these residues is related to peel byproduct that represents between $50 \%$ and $65 \%$ of the total weight of the fruit; reported chemical analysis for orange peel showed $7.1 \%$ protein and $12.79 \%$ crude fiber. In addition, limonoids and flavonoids with antioxidant activity were also found in orange peel. This antioxidant activity of citrus peel extracts comes from glycosides hesperidin and naringin present in this extract. Orange peel also contains coniferin and phlorin as additional phenols that help in radical scavenging when administered in the form of orange peel molasses, and this will promote sustainable disposal of orange peels [64].

In this study, orange peel extract was used as an effective chelating agent to synthesize molybdenum oxides. $\mathrm{MoO}_{3}$ and $\mathrm{MoO}_{2}$ were prepared by altering the calcination conditions: in air for $\mathrm{MoO}_{3}$ and in vacuum for $\mathrm{MoO}_{2}$ at a low temperature of $450{ }^{\circ} \mathrm{C}$. The as-prepared oxides were subjected to various characterizations, including $X$-ray diffraction (XRD), thermogravimetric analysis (TGA), scanning electron microscopy (SEM), transmission electron microscopy (TEM), Raman scattering (RS) spectroscopy, and X-ray photoelectron spectroscopy (XPS), to elucidate their morphological and structural properties. Further electrical and electrochemical characterizations, including cyclic voltammetry (CV), galvanostatic charge-discharge (GCD), electrochemical impedance spectroscopy (EIS), and area-specific impedance (ASI), were carried out for the as-prepared molybdenum oxides as anode materials for LIBs.

\section{Materials and Methods}

Ammonium molybdate, conductive carbon black super C65 (Timcal Co., Bodio, Switzerland), binder polyvinylidene fluoride (PVDF, 12 wt.\%, Kureha Battery Materials Japan Co., Tokyo, Japan), solvent 1-methyl-2-pyrrolidinone (NMP, anhydrous 99.5\%, SigmaAldrich, Burlington, MA, USA), electrolyte $1 \mathrm{~mol} \mathrm{~L}^{-1} \mathrm{LiPF}_{6}$ in ethylene and dimethyl carbonate solution mixed as a 1:1 volume ratio (BASF Corporation, Ludwigshafen-am-Rhein, Germany), and lithium ribbon (thickness $0.38 \mathrm{~mm}, 99.9 \%$ trace metals basis, Sigma-Aldrich, Burlington, MA, USA) were employed as received.

Molybdenum oxides were prepared by the sol-gel method using ammonium molybdate tetrahydrate, $\left(\mathrm{NH}_{4}\right)_{6} \mathrm{Mo}_{7} \mathrm{O}_{24} \cdot 4 \mathrm{H}_{2} \mathrm{O}$ as the source of molybdenum, and extract of orange peel as the chelating agent. Pure filtrated extract of orange peel was obtained through boiling small pieces of cleaned waste peels in distilled water at $100{ }^{\circ} \mathrm{C}$ for $10 \mathrm{~min}$. A schematic representation of the $\mathrm{MoO}_{3}$ and $\mathrm{MoO}_{2}$ growth process is shown in Figure 1. Pure orange peel extract drops were added with vigorous stirring to a $100 \mathrm{~mL}$ solution of $4 \mathrm{~g}$ of $\left(\mathrm{NH}_{4}\right)_{6} \mathrm{Mo}_{7} \mathrm{O}_{24} \cdot 4 \mathrm{H}_{2} \mathrm{O}$. During this operation, the solution changed in color from yellow to blue until conversion to a dark gel. The dry xerogel (precursor) was divided into two parts: one part was calcined in air at $450{ }^{\circ} \mathrm{C}$ for $5 \mathrm{~h}$ (MOA, yellow color) and the second was calcined under vacuum at $450{ }^{\circ} \mathrm{C}$ for $5 \mathrm{~h}$ (MOV, black color). 


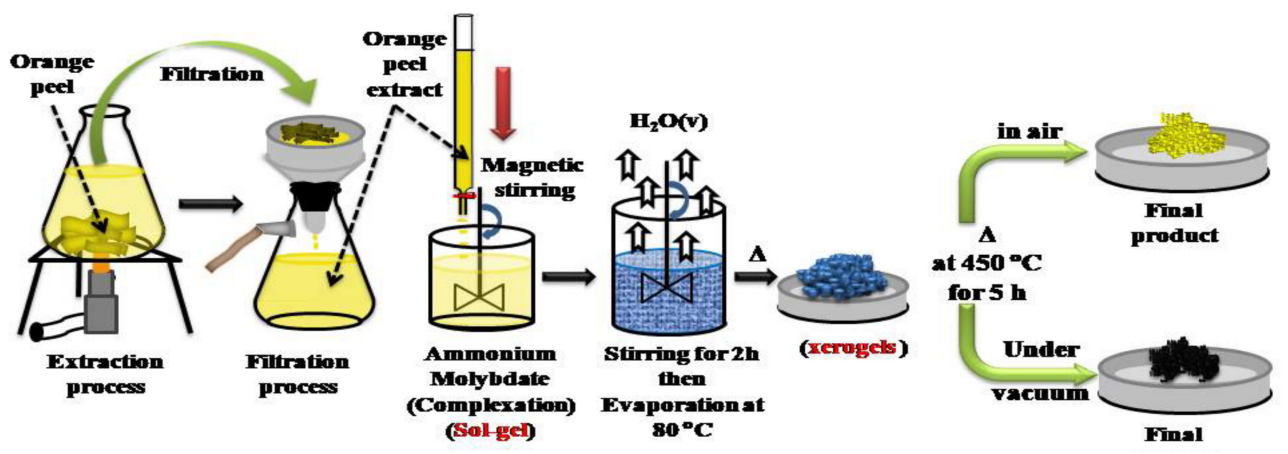

Figure 1. Schematic diagram for the synthesis of $\mathrm{MoO}_{3}$ (yellow color) and $\mathrm{MoO}_{2}$ (black).

XRD analyses of as-prepared samples were processed using a Bruker D8 Discover XRD Instrument equipped with $\mathrm{CuK}_{\alpha}$ radiation $(\lambda=1.5406 \AA)$. The scanning rate was $1.2^{\circ} \mathrm{min}^{-1}$, for $2 \theta$ between $10^{\circ}$ and $80^{\circ}$. Raman spectra were recorded at room temperature with a micro-Raman spectrometer (Renishaw, Wotton-under-Edge, UK) with a confocal Raman microscope inVia ${ }^{\mathrm{TM}}$ system at a $532 \mathrm{~nm}$ laser-line excitation. The spectra were calibrated with the reference Si phonon peak at $520 \mathrm{~cm}^{-1}$. The morphology of the materials was studied by field emission scanning electron microscopy (FESEM, JEOL JSM-7800F) and by transmission electron microscopy (TEM, JEOL, JEM-2100 microscope, Japan). BET surface area and pore size distribution of synthesized samples were determined from an $\mathrm{N}_{2}$-physisorption analyzer (ASAP 2020 system, Micromeritics Corporate, Norcross, GA, USA). The BET surface area was calculated from the isotherms in the range from 0.02 to 0.4 of relative pressures $\left(P / P_{0}\right)$. TGA measurements were carried out for the prepared samples using a thermal gravimetric analyzer (Perkin Elmer, TGA 7 series) in a temperature range of $50-1000{ }^{\circ} \mathrm{C}$ at a heating rate of $10{ }^{\circ} \mathrm{C} \mathrm{min}{ }^{-1}$ in air. X-ray photoelectron spectra were recorded using a PHI VersaProbe II Scanning X-Ray Microprobe system equipped with a $\operatorname{Mg} \mathrm{K} \alpha$ source $(\lambda=1253.6 \mathrm{eV})$.

LIB electrodes were fabricated as a mixture of active materials (Mo oxide powders), carbon black (CB), and polyvinylidene fluoride binder (PVDF) in a 5:3:2 mass ratio. We used a high percentage of carbon black and PVDF binder in the electrode to maintain the mechanical integrity and good electrical connection in the electrode during long-term cycling experiment. The mixture was added to N-methyl-2-pyrrolidone (NMP) solvent. The mixed slurry was magnetically stirred for $24 \mathrm{~h}$ to form a homogeneous blend. The wellblended slurry was cast on a copper foil by a doctor blade and was dried under vacuum at $100{ }^{\circ} \mathrm{C}$ for $24 \mathrm{~h}$. Finally, electrodes were punched out as $\sim 0.97 \mathrm{~cm}^{2} \operatorname{discs}(\Phi=11 \mathrm{~mm})$. CR2032 coin cells processed in an argon-filled glovebox using $30 \mu \mathrm{L}$ electrolyte dripped on the electrode, then on a Celgard 2400 separator. Electrochemical tests were carried out using an Arbin BT2000 battery cycler at room temperature. Before cycling, cells were initially maintained at rest for $30 \mathrm{~min}$. Cells were cycled galvanostatically at C/10 and 1C-rate $\left(1 \mathrm{C}=838 \mathrm{~mA} \mathrm{~g}^{-1}\right.$ for $\mathrm{MoO}_{2}$ and $1 \mathrm{C}=1117 \mathrm{~mA} \mathrm{~g}^{-1}$ for $\left.\mathrm{MoO}_{3}\right)$ in a voltage range between 0.01 and $3.0 \mathrm{~V}$. Cyclic voltammetry was conducted at room temperature on a BioLogic VSP workstation in which the potential was set to sweep from open-circuit voltage to $0.01 \mathrm{~V}$ and then to sweep back to $3.0 \mathrm{~V}$ at a $0.02 \mathrm{mV} \mathrm{s}^{-1}$ scanning rate. Electrochemical impedance spectroscopy was also conducted by the VSP workstation in the frequency range from $5 \times 10^{5}$ to $0.1 \mathrm{~Hz}$ with an amplitude of $5 \mathrm{mV}$.

\section{Results}

\subsection{Structure and Morphology}

The X-ray diffractograms of MOA and MOV materials are shown in Figure 2a. Patterns display well-resolved reflections with a very smooth background indicating the high crystallinity of Mo oxides prepared by the sol-gel method with biological chelating agent and final calcination at $450{ }^{\circ} \mathrm{C}$. The XRD spectrum of MOA exhibited the typical pattern of the $\alpha-\mathrm{MoO}_{3}$ phase and can be indexed in the orthorhombic structure with Pbnm space 
group (JPCDS card 76-1003) [65]. The presence of a preferred orientation of (0k0) planes was evidenced by the (020), (040), and (060) Bragg lines with large intensities. The XRD spectrum of the MOV material displayed sharp diffraction peaks indicating the formation of highly crystallized $\mathrm{MoO}_{2}$, which can be indexed using the monoclinic structure with the $P 2_{1} / c$ space group (JPCDS card 68-0135). In order to characterize the phase purity as well as the phase composition, the full structural identification of the $\mathrm{MoO}_{3}$ and the $\mathrm{MoO}_{2}$ powders were analyzed using Rietveld refinements. The results are listed in Table 1, and the refined XRD spectra are displayed in Figure $2 b, c$. The small values of the residual and reliability parameters $\left(R_{\mathrm{p}}, R_{\mathrm{w}}\right.$, and $\left.\chi^{2}\right)$ of the Rietveld refinement indicate the successful identification of the orthorhombic and monoclinic phases of $\mathrm{MoO}_{3}$ and $\mathrm{MoO}_{2}$ powders, respectively, even in the presence of some impurity phases as in the case of MOV. The lattice parameters obtained from Rietveld refinement are in good agreement with values of our previous work as well as other literature [22,66-68]. A careful examination of the $\mathrm{MoO}_{2}$ sample calcinated in vacuum reveals the presence of a small amount of Mo-suboxides such as $\mathrm{Mo}_{4} \mathrm{O}_{11}, \mathrm{Mo}_{8} \mathrm{O}_{23}$, and $\mathrm{Mo}_{9} \mathrm{O}_{26}$ (Table 1). These compositions belong to $\mathrm{Mo}_{\mathrm{n}} \mathrm{O}_{3 \mathrm{n}-1}$ suboxides (Magnéli phases, $n=4-9$ ), which crystallize into the $\mathrm{ReO}_{3}$-type structure characterized by the presence of empty channels due to the loss of oxygen $[23,68,69]$. These compositions $\left(\mathrm{Mo}_{4} \mathrm{O}_{11}, \mathrm{Mo}_{8} \mathrm{O}_{23}\right.$, and $\left.\mathrm{Mo}_{9} \mathrm{O}_{26}\right)$ deduced form Rietveld refinement imply the presence of a mixture of Mo with oxidation states between +6 and +4 . This electronic configuration implies a concentration of free carriers and, thus, a large electrical conductivity, which is beneficial to electrochemical properties [68].
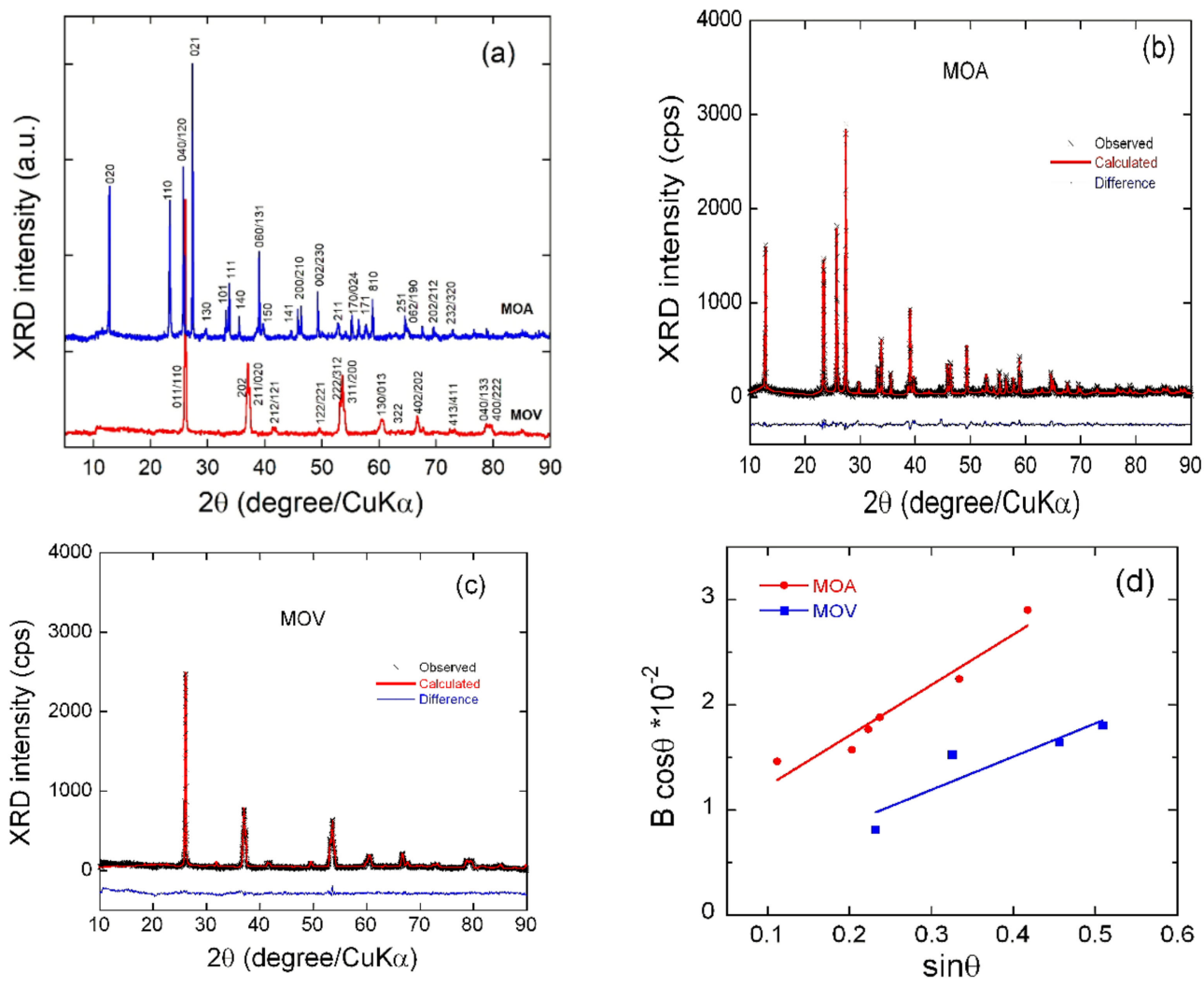

Figure 2. (a) XRD patterns of the as-prepared MOA and MOV samples. (b) Rietveld refinement of the MOA sample. (c) Rietveld refinement of the MOV sample. Cross marks are experimental data and solid lines (in red) are calculated diagrams. The curve at the bottom is the difference between the calculated and observed intensities. (d) Analysis of micro-strain from the full-width $B$ at half-maximum of the XRD peaks according to Equation (1). 
Table 1. Results of the Rietveld refinements for the MOA and MOV samples.

\begin{tabular}{ccc}
\hline Crystal data & MOA & MOV \\
\hline Lattice parameters & $3.69(5)$ & \\
$a(\AA)$ & $13.84(8)$ & $5.61(3)$ \\
$b(\AA)$ & $3.95(9)$ & $4.85(3)$ \\
$c(\AA)$ & 202.6 & $5.62(1)$ \\
$V\left(\AA^{3}\right)$ & 29.5 & 131.3 \\
$L_{c}(\mathrm{~nm})$ & 11.9 & 45.6 \\
$\varepsilon \times 10^{-2}(\mathrm{rd})$ & & 7.9 \\
Reliability factors & 10.9 & \\
$R_{p}(\%)$ & 16 & 8.1 \\
$R_{\text {wop }}(\%)$ & 9.1 & 11.2 \\
$R_{\text {exp }}$ & 3.1 & 7.7 \\
$\chi^{2}$ & & 2.1 \\
$\mathrm{MoO}_{3}$ & 100 & 0 \\
$\mathrm{MoO}_{2}$ & 0 & 90.2 \\
$\mathrm{Mo}_{4} \mathrm{O}_{11}$ & 0 & 2.2 \\
$\mathrm{Mo}_{8} \mathrm{O}_{23}$ & 0 & 4.5 \\
$\mathrm{Mog}_{9} \mathrm{O}_{26}$ & 0 & 3.1 \\
\hline
\end{tabular}

The formation of $\mathrm{Mo}_{4} \mathrm{O}_{11}, \mathrm{Mo}_{8} \mathrm{O}_{23}$, and $\mathrm{Mo}_{9} \mathrm{O}_{26}$ suboxides under vacuum is due to the presence of not only the ammonia in ammonium molybdate but also the $\mathrm{CO}$ and $\mathrm{CO}_{2}$ gases generated by the combustion reaction of carbon found in the organic components of orange peel (i.e., ascorbic and citric acid) which reduce the $\mathrm{Mo}^{6+}$ ions in absence of $\mathrm{O}_{2}$. The average crystalline sizes of the prepared samples were calculated using the DebyeScherrer's formula from the full-width of diffraction peaks. They were found to be $\approx 29$ and $45 \mathrm{~nm}$ for MOA and MOV, respectively. Further information on the structural properties can be obtained from the broadening of diffraction peaks that is considered an indicator, not only of the crystallinity of the MOA and MOV powder, but also of the homogeneous distribution of cations over the structure. The micro-strain $(\varepsilon)$ of the MOA and MOV particles was determined using the Williamson-Hall equation [70]:

$$
B_{\mathrm{hkl}} \cos \theta_{\mathrm{hkl}}=\left(K \lambda / L_{\mathrm{c}}\right)+4 \varepsilon \sin \theta_{\mathrm{hkl}}
$$

where $B_{\mathrm{hkl}}$ is the line broadening of a Bragg reflection $(h k l), K$ is the shape factor, $L_{\mathrm{c}}$ is the effective crystallite size, and $\lambda$ is the $X$-ray wavelength. The micro-strain is estimated from the slope of the plot $\left(B_{\mathrm{hkl}} \cos \theta_{\mathrm{hkl}}\right)$ vs. $\left(\sin \theta_{\mathrm{hkl}}\right)$ and the intersection with the vertical axis provides the crystallite size. The $B_{\mathrm{hkl}}$ value used here was the instrumentally corrected one. From Figure $2 \mathrm{~d}$, the micro-strain was determined to be $11.9 \times 10^{-2}$ and $7.9 \times 10^{-2} \mathrm{rd}$ for MOA and MOV, respectively, showing a slight difference in the crystallinity of the samples, as the micro-strain was strongly affected by the heat-treatment conditions.

Figure 3 displays the thermogravimetry (TG) curves of MOA and MOV samples recorded at a heating rate of $10{ }^{\circ} \mathrm{C} \mathrm{min}-1$. The MOA sample showed a stable, flat, and straight-line TG profile without weight change until the start of decomposition above $730{ }^{\circ} \mathrm{C}$. These features indicate a stochiometric $\mathrm{MoO}_{3}$ material without any oxygen vacancies or carbon coating due to the burning of the extract of organic peel. On the contrary, the thermal behavior of reduced MOV looked different. The TG curve was stable and flat until approximately $400{ }^{\circ} \mathrm{C}$. Above $400{ }^{\circ} \mathrm{C}$, a gradual and pronounced weight gain occurred until reaching the highest value of $10.4 \%$ weight gain, which was due to the re-oxidation and filling of oxygen vacancies in the suboxide $\left(\mathrm{Mo}_{4} \mathrm{O}_{11}, \mathrm{Mo}_{8} \mathrm{O}_{23}\right.$, and $\left.\mathrm{Mog}_{9} \mathrm{O}_{26}\right)$ lattices, and the transformation of $\mathrm{MoO}_{2}$ to the stoichiometric $\mathrm{MoO}_{3}$ phase at $T=600{ }^{\circ} \mathrm{C}$. Theoretically, the weight gain for the conversion of $\mathrm{MoO}_{2}$ to $\mathrm{MoO}_{3}$ was approximately $12.5 \%$. From the TG analysis, it was observed that the weight of the sample increased by $\approx 10.4 \%$ from room temperature to $600{ }^{\circ} \mathrm{C}$ in the air. Thus, the calculated value for conversion of $\mathrm{MoO}_{2}$ and 
the suboxides (i.e., $\mathrm{Mo}_{4} \mathrm{O}_{11}, \mathrm{Mo}_{8} \mathrm{O}_{23}<$ and $\mathrm{Mo}_{9} \mathrm{O}_{26}$ ) to the stoichiometric $\mathrm{MoO}_{3}$ is close to the theoretical value. It is worth noting that the color of $\mathrm{MoO}_{2}$ was black before the TG measurements and converted to the color yellow after the TG runaway to $600{ }^{\circ} \mathrm{C}$. In addition, this TG of MOV confirmed that there was no carbon coating around their particles. This was because there was no weight loss above $500{ }^{\circ} \mathrm{C}$ related to the emission of $\mathrm{CO}_{2}$ as a result of the reaction between oxygen in the air and carbon, if present. However, some mass loss might occur, which was masked by oxygen gain during the oxidation process.

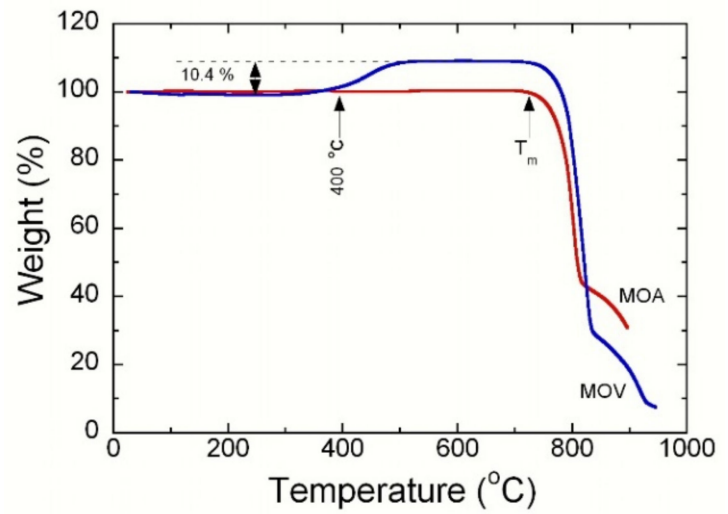

Figure 3. Thermogravimetry (TG) curves of the MOA and MOV samples recorded at a heating rate of $10^{\circ} \mathrm{C} \mathrm{min}-1$. MOA displays the typical behavior of the stoichiometric $\mathrm{MoO}_{3}$ orthorhombic phase, while MOV shows the oxidation of the suboxide at $400{ }^{\circ} \mathrm{C}$ and the conversion to $\mathrm{MoO}_{3}$ at $600{ }^{\circ} \mathrm{C}$.

The SEM images $(\mathrm{a}-\mathrm{c})$ and TEM image $(\mathrm{d})$ of the MOA and MOV samples depicted in Figure 4 illustrate the influence of the synthesis conditions on the particle size and morphology. There is a significant difference between the morphology of molybdenum oxide prepared in air and that prepared in vacuum from the same ammonium molybdate tetrahydrate precursor. Air calcination gives heterogeneous MOA particles with wellcrystallized crystals a platelet-like shape (Figure $4 \mathrm{a}, \mathrm{c}$ ). The sizes of the MOA particles were in a wide range from the sub-micrometer to $\sim 10 \mu \mathrm{m}$ [71]. On the contrary, calcination in vacuum provided homogeneous MOV powders with an ash-like morphology at the nanometer size (Figure 4b). SEM (Figure 4c) and TEM images (Figure 4d) show that the MOA platelets had sizes larger than $1 \mu \mathrm{m}$, while the MOV powders had smaller sizes, in the $40-100 \mathrm{~nm}$ range. The size and morphology differences of the MOA and MOV particles were mainly due to the heat treatment conditions.

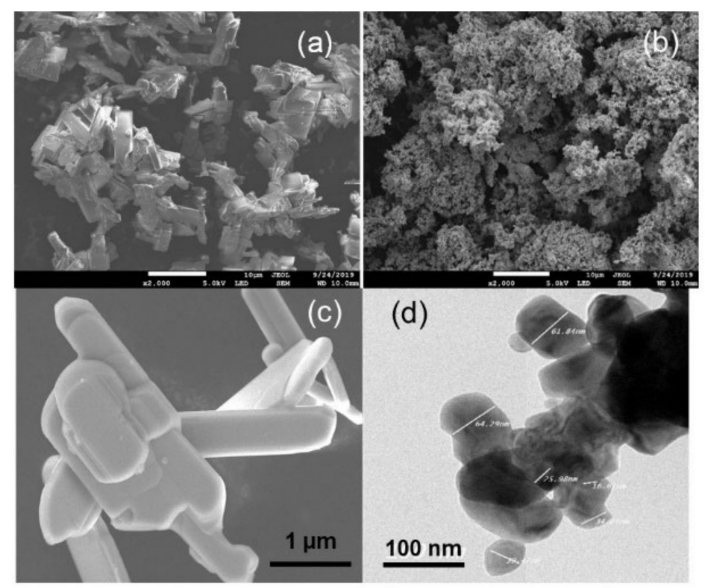

Figure 4. (a,b) SEM images of the MOA and MOV samples synthesized using a sol-gel method assisted by a biological chelator (scale bar of $10 \mu \mathrm{m}$ ). (c) Magnified SEM image of the MOA (scale bar of $1 \mu \mathrm{m}$ ) and a (d) TEM image of the MOV sample (scale bar of $100 \mathrm{~nm}$ ). 
Raman spectroscopy is a sensitive tool for investigating the coordination, structure, lattice vibrations, and symmetry of molybdenum and oxygen atoms in the presence of different phases. Further structural analyses of as-prepared molybdenum oxides were carried out by Raman scattering spectroscopy using the excitation line at $\lambda_{\text {exc }}=532 \mathrm{~nm}$ (Figure 5a-d). The Raman spectrum of the MOA sample (Figure 5a) displays the typical vibrational features of the orthorhombic $\alpha-\mathrm{MoO}_{3}$ phase. Twelve vibrational modes were evidenced by the peaks located at 197, 216, 245, 283, 290, 336, 364, 378, 471, 665, 818, and $995 \mathrm{~cm}^{-1}$. The wavenumbers and relative intensities matched closely with the single crystal Raman spectrum given in the literature [72-76]. Most of the Raman active modes were dominated by either interlayer or intralayer contributions. More specifically, the peak at $665 \mathrm{~cm}^{-1}$ was related to the $v\left(\mathrm{O}-\mathrm{Mo}_{3}\right)$ stretching mode of the triply-coordinated oxygen atoms, which are shared by three $\mathrm{MoO}_{6}$ octahedra. The intense peak at $818 \mathrm{~cm}^{-1}$ was linked to the doubly-coordinated oxygen $v\left(\mathrm{O}-\mathrm{Mo}_{2}\right)$ stretching mode. The high-wavenumber peak at $995 \mathrm{~cm}^{-1}$ was associated with the $v\left(\mathrm{Mo}^{6+}=\mathrm{O}\right)$ asymmetric stretching mode of terminal singly-coordinated (unshared) oxygen atoms, which had bonds that were responsible for the layered structure of the $\alpha-\mathrm{MoO}_{3}$ orthorhombic phase [75]. Figure $5 b-\mathrm{d}$ presents the micro-Raman spectra of the MOV sample recorded on different areas of the sample using $1 \%$ laser power $(0.5 \mathrm{~mW})$ at a $532 \mathrm{~nm}$ laser-line excitation. The micro-Raman results were in good agreement with the XRD findings. The mixture of vibrational features of the $\mathrm{MoO}_{2}$ and $\mathrm{Mo}_{n} \mathrm{O}_{3 n-1}$ suboxide phases (i.e., o- $\mathrm{Mo}_{4} \mathrm{O}_{11}, \mathrm{~m}-\mathrm{Mo}_{8} \mathrm{O}_{23}$, o- $\mathrm{Mo}_{9} \mathrm{O}_{26}$ Magnéli) can be identified [77-83]. The Raman bands of the MOV sample located at 126, 203, 228, 346, 362, $458,470,495,570,585$, and $741 \mathrm{~cm}^{-1}$ (Figure 5b) correspond to a rutile-type (monoclinic) structure and agreed well with the vibrational features of the $\mathrm{m}-\mathrm{MoO}_{2}$ reported in the literature [77-80]. Two weaker peaks, located at 425 and $820 \mathrm{~cm}^{-1}$, were attributed to the orthorhombic o- $\mathrm{Mo}_{4} \mathrm{O}_{11}$ suboxide $[81,83]$.
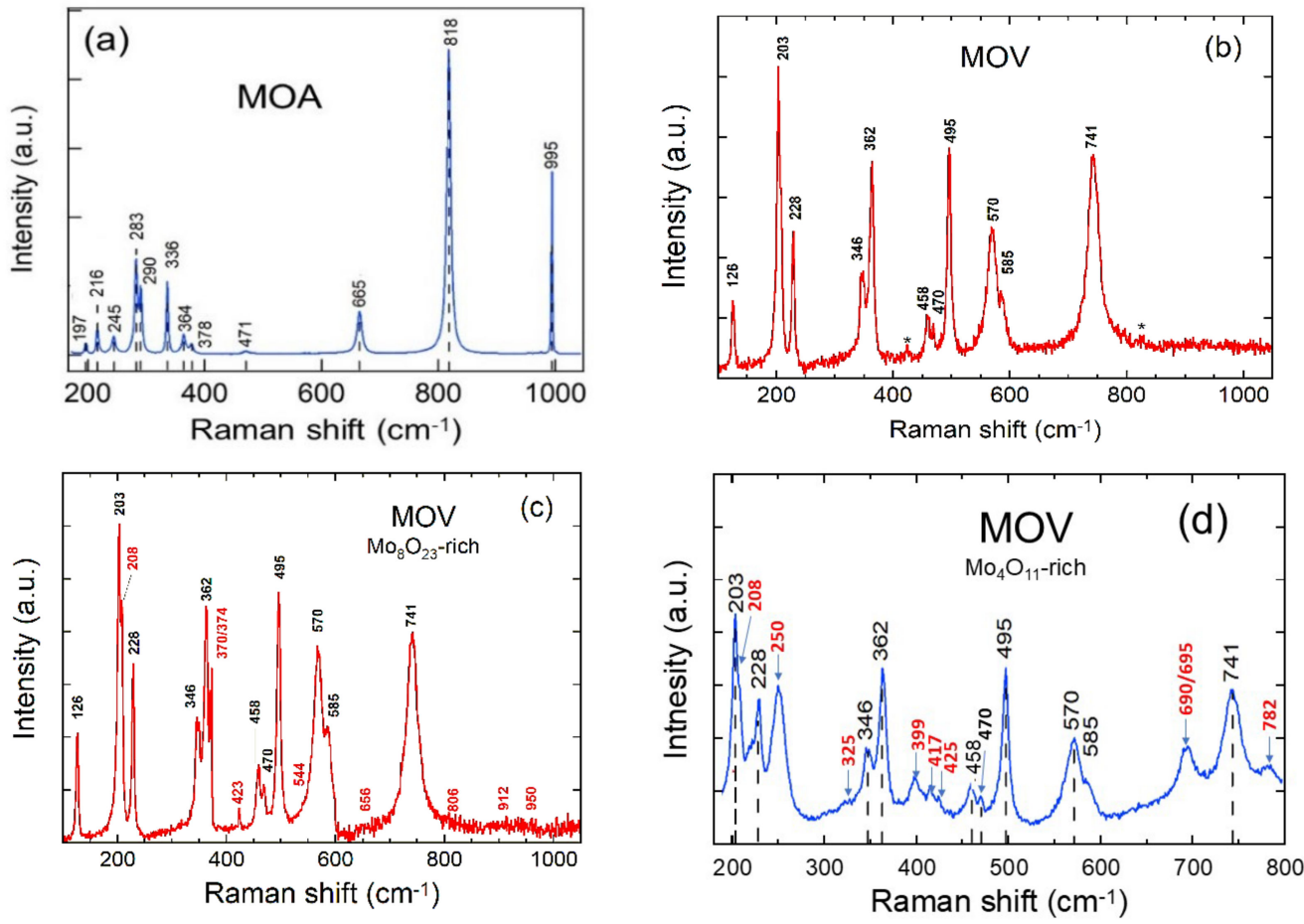

Figure 5. Raman spectra of the (a) MOA powders, (b) $\mathrm{MOV}\left(\mathrm{MoO}_{2}\right.$-rich sample where the stars correspond to Raman peaks of suboxides), (c) $\mathrm{MOV}$ with m- $\mathrm{Mo}_{8} \mathrm{O}_{23}$-rich particles, and (d) MOV with o- $\mathrm{Mo}_{4} \mathrm{O}_{11}$-rich particles. Spectra were recorded at a spectral resolution of $1 \mathrm{~cm}^{-1}$.

Vibrational analysis of the $\mathrm{MoO}_{2}$ spectrum reveals that the bands in the 500-800 and 200-400 $\mathrm{cm}^{-1}$ regions were due to $\mathrm{Mo}-\mathrm{O}$ stretching and bending modes, respectively. The low-frequency region $\left(<200 \mathrm{~cm}^{-1}\right)$ corresponded to the lattice modes. The Raman spectra 
of suboxide-rich areas are displayed in Figure $5 \mathrm{c}, \mathrm{d}$ for the $\mathrm{MOV}$ with $\mathrm{m}-\mathrm{Mo}_{8} \mathrm{O}_{23}$-rich and $\mathrm{o}-\mathrm{Mo}_{4} \mathrm{O}_{11}$-rich particles, respectively (Raman peaks of suboxides are marked in red). The monoclinic $\mathrm{m}-\mathrm{Mo}_{8} \mathrm{O}_{23}$ phase is identified through the Raman peaks at 208, 370/374, 656, 912 , and $950 \mathrm{~cm}^{-1}$, whereas peaks located at 208, 250, 325, 399, 417, 425, 695, 782, 806, and $912 \mathrm{~cm}^{-1}$ are assigned to the o- $\mathrm{Mo}_{4} \mathrm{O}_{11}$ phase. Moreover, the MOV sample contained a small amount of the $\mathrm{o}-\mathrm{Mo}_{9} \mathrm{O}_{26}$ suboxide identified by the peaks at 208, 544, 782, 912, and $950 \mathrm{~cm}^{-1}$. The spectroscopic results are listed in Table 2 and compared with the literature data $[81,82]$.

Table 2. Reported Raman peak frequencies $\left(\mathrm{cm}^{-1}\right)$ of $\mathrm{M}-\mathrm{O}$ oxides.

\begin{tabular}{cccccccccc}
\hline \multicolumn{2}{c}{$\boldsymbol{\alpha}-\mathbf{M o O}_{\mathbf{3}}$} & \multicolumn{2}{c}{$\mathbf{m}-\mathbf{M o O}_{\mathbf{2}}$} & \multicolumn{2}{c}{$\mathbf{o -}-\mathbf{M o}_{\mathbf{4}} \mathbf{O}_{\mathbf{1 1}}$} & \multicolumn{2}{c}{$\mathbf{m}-\mathbf{M o}_{\mathbf{8}} \mathbf{O}_{\mathbf{2 3}}$} & \multicolumn{2}{c}{$\mathbf{o - M o} \mathbf{O}_{\mathbf{2 6}}$} \\
\hline Exp. & {$[81]$} & Exp. & {$[82]$} & Exp. & {$[82]$} & Exp. & {$[82]$} & Exp. & [82] \\
\hline 197 & - & 126 & - & 208 & 208 & & & 208 & 208 \\
216 & 217 & 203 & 208 & 250 & 253 & 208 & 208 & - & 465 \\
245 & 245 & 228 & 232 & - & 281 & - & 222 & 544 & 575 \\
283 & 284 & 346 & 353 & 325 & 339 & 374 & 373 & - & 622 \\
290 & 291 & 362 & 370 & 399 & 380 & - & 384 & - & 637 \\
336 & 338 & 458 & 448 & 417 & 413 & - & 592 & - & 679 \\
364 & 365 & 470 & 473 & 425 & 435 & 656 & 654 & 782 & 761 \\
378 & 379 & 495 & 501 & 695 & 714 & - & 875 & 912 & 906 \\
471 & 472 & 570 & 572 & 782 & 787 & 912 & 918 & - & 931 \\
665 & 666 & 585 & 590 & 806 & 837 & 950 & 951 & 950 & 951 \\
818 & 820 & 741 & 748 & 912 & 916 & & & - & 989 \\
995 & 996 & & & - & 963 & & & & \\
\hline
\end{tabular}

XPS measurements were carried out to evaluate the chemical composition and investigate the surface valance states of Mo in MOA and MOV samples. The results are shown in Figure 6. The survey spectra (Figure 6a) display the fingerprints of the Mo $3 \mathrm{~d}, \mathrm{Mo3} \mathrm{p}_{3 / 2}, \mathrm{Mo}_{\mathrm{p}} \mathrm{p}_{1 / 2}$, and O1s core levels (their binding energies are listed in Table 3). The Mo 3d and O1s peaks were analyzed by evaluating the peak area of elements using Gaussian profiles after removing the secondary electron background. All XPS spectra can be deconvoluted using two Mo $3 d$ doublets with $3 d_{5 / 2}$ and $3 d_{3 / 2}$ species. For the MOA sample (Figure 6b), the Mo $3 \mathrm{~d}_{5 / 2}$ and Mo3d $\mathrm{d}_{3 / 2}$ characteristic peaks were located at 232.6 and $235.7 \mathrm{eV}$, respectively (with a spin-orbit separation of $\sim 3.1 \mathrm{eV}$ ), suggesting the sole existence of $\mathrm{Mo}^{6+}$ species on the MOA surface $[23,84,85]$. The binding energy of the Mo $3 \mathrm{~d}_{5 / 2}$ line for polycrystalline $\mathrm{MoO}_{3}$ has been reported to be 231.6-s232.7 eV [86-88]. For the MOV sample, the deconvoluted peaks in Figure 6c unambiguously reveal the co-existence of mixed Mo valence states (Table 3).

Table 3. XPS analysis of the MOA and MOV samples.

\begin{tabular}{|c|c|c|c|c|c|c|c|c|c|c|}
\hline \multirow{3}{*}{ Sample } & \multicolumn{9}{|c|}{ Binding Energy (eV) } & \multirow{3}{*}{$\begin{array}{c}\text { Average } \\
\text { Mo } \\
\text { Valence } \\
\text { State }\end{array}$} \\
\hline & \multirow{2}{*}{$\operatorname{Mo3p}_{3 / 2}$} & \multirow{2}{*}{$\operatorname{Mo3p}_{1 / 2}$} & \multirow{2}{*}{ O1s } & \multicolumn{4}{|c|}{$\operatorname{Mo3d}_{5 / 2}$} & \multicolumn{2}{|c|}{$\operatorname{Mo3d}_{3 / 2}$} & \\
\hline & & & & $\mathrm{Mo}^{4+}$ & $\mathrm{Mo}^{5+}$ & $\mathrm{Mo}^{6+}$ & $\mathrm{Mo}^{4+}$ & $\mathrm{Mo}^{5+}$ & $\mathrm{Mo}^{6+}$ & \\
\hline MOA & 398.9 & 415.5 & 530.5 & - & - & 232.6 & - & - & 235.7 & 6.00 \\
\hline MOV & 398.9 & 415.5 & 530.6 & 233.1 & 230.0 & 231.6 & 236.3 & 233.3 & 234.7 & 4.39 \\
\hline
\end{tabular}



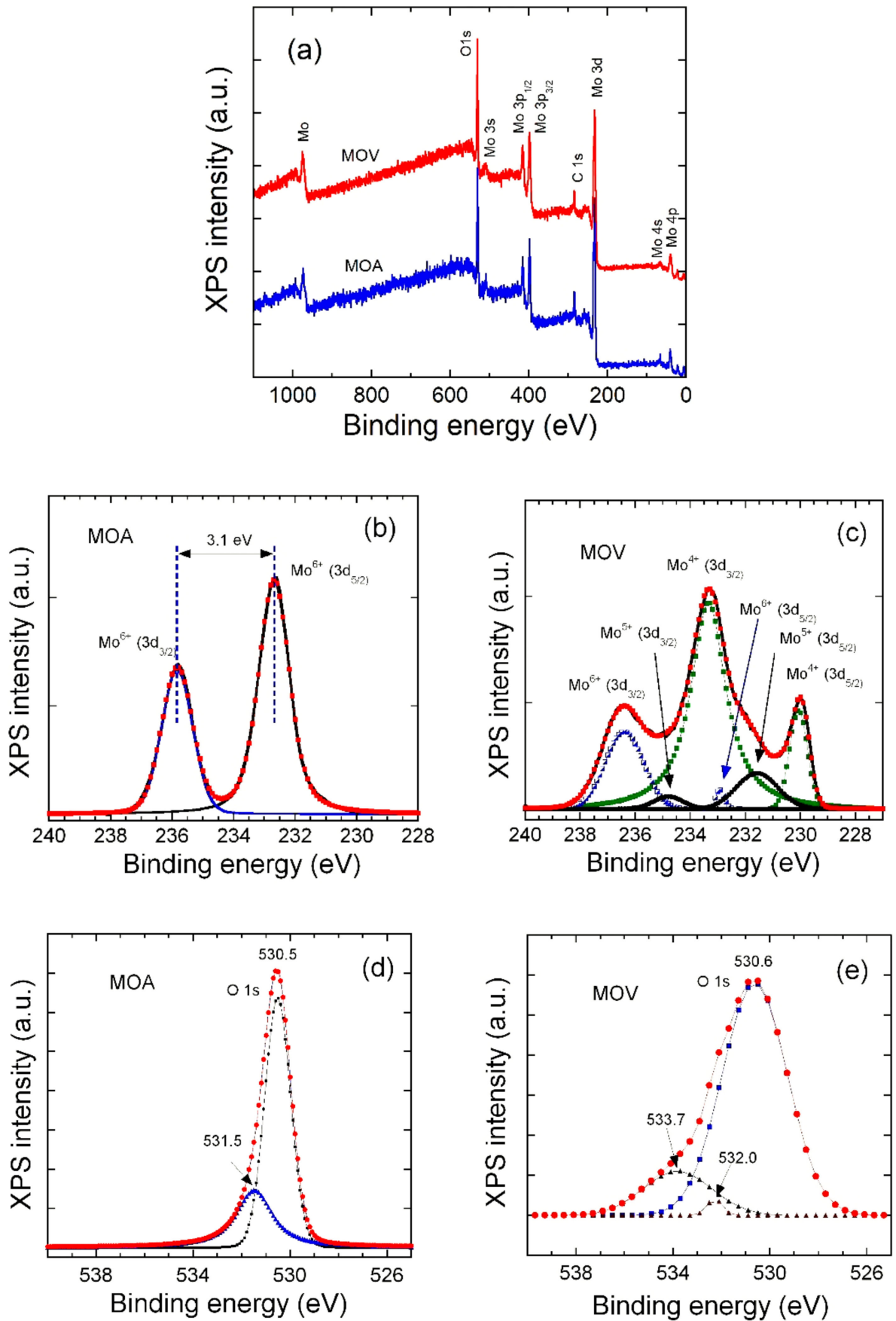

Figure 6. (a) XPS survey spectra of the MOA and MOV samples. High-resolution XPS spectra of (b) Mo 3d in MOA, (c) Mo 3d in MOV, (d) O1s in MOA, (e) O1s in MOV.

The first doublet centered at 230 and $233.3 \mathrm{eV}$ was typically the Mo $3 \mathrm{~d}_{5 / 2}$ and Mo $3 \mathrm{~d}_{3 / 2}$ of $\mathrm{Mo}^{4+}$, respectively, whereas the second one located at 231.6 and $234.7 \mathrm{eV}$ was due to the $\mathrm{Mo}^{5+}$, and, finally, the last one located at 233.1 and $236.3 \mathrm{eV}$ was due to the $\mathrm{Mo}^{6+}[88,89]$. The XPS spectra of O1s are presented in Figure 6d,e for the MOA and MOV samples, respectively. The intense peak located at $\sim 530.5 \pm 0.1 \mathrm{eV}$ was attributed to the binding energy of Mo-O bonds, whereas the peak at a higher binding energy was assigned to surface states. Therefore, the surface states of the MOV observed in the XPS patterns ascribed the presence of $\mathrm{MoO}_{2}, \mathrm{Mo}_{4} \mathrm{O}_{11}, \mathrm{Mo}_{8} \mathrm{O}_{23}$, and $\mathrm{Mo}_{9} \mathrm{O}_{26}$ (Figure 6c). From XPS peak deconvolution, the average Mo valence state of the MOA and MOV sample was determined to be 6.00 and 4.39 , respectively. 
The porous texture of the MOA and MOV samples was investigated by the $\mathrm{N}_{2}$ adsorption-desorption isotherm measurement. The isotherm profiles of samples can be categorized as a type IV curve with a H3 hysteresis loop at the relative pressure of 0.8-1.0, thus implying the existence of a large number of mesopores. The average pore size was below $2 \mathrm{~nm}$ in the MOV material, while the MOA sample exhibits an average pore size of $10 \mathrm{~nm}$. Moreover, the Brunauer-Emmett-Teller (BET) specific surface area of the MOV was $4.0 \mathrm{~m}^{2} \mathrm{~g}^{-1}$, which was higher than that of the MOA $\left(0.23 \mathrm{~m}^{2} \mathrm{~g}^{-1}\right)$. The mesoporous structure of the Mo-O samples may be beneficial for the electrolyte to penetrate completely into the pores and diffuse efficiently to active sites with less resistance, and can also buffer large volume change during the $\mathrm{Li}^{+}$-ion insertion/extraction processes. The equivalent particle size of the MOA and MOV samples can be calculated from the BET data and compared using SEM images. The average particle size ( $\mathrm{nm}$ ) is expressed by Equation (6) below [90]:

$$
L_{\mathrm{BET}}=\frac{6000}{S_{\mathrm{BET}} d^{\prime}}
$$

where $S_{\mathrm{BET}}$ is the specific surface area (in $\mathrm{m}^{2} \mathrm{~g}^{-1}$ ) measured by BET experiments, and $d$ is the gravimetric density (4.70 and $6.47 \mathrm{~g} \mathrm{~cm}^{-3}$ for $\mathrm{MoO}_{3}$ and $\mathrm{MoO}_{2}$, respectively). Results of the sample texture are summarized in Table 4 . Note that the $L_{\text {BET }}$ values corresponded to the average size of the secondary particles (agglomerates observed in SEM images).

Table 4. BET specific surface area $\left(S_{\mathrm{BET}}\right)$ and average pore size and pore volume of the MOA and MOV samples.

\begin{tabular}{ccccc}
\hline Sample & $\begin{array}{c}S_{\text {BET }} \\
\left(\mathbf{m}^{\mathbf{2}} \mathbf{g}^{-\mathbf{1}}\right)\end{array}$ & $\begin{array}{c}\text { Pore Size } \\
(\mathbf{n m})\end{array}$ & $\begin{array}{c}\text { Pore Volume } \\
\left(\mathbf{c m}^{\mathbf{3}} \mathbf{g}^{-\mathbf{1}}\right)\end{array}$ & $\begin{array}{c}L_{\text {BET }} \\
(\mathbf{n m})\end{array}$ \\
\hline MOA & 0.23 & 10 & 0.0012 & 3500 \\
MOV & 4.00 & $\sim 2$ & 0.0002 & 231 \\
\hline
\end{tabular}

\subsection{Electrochemical Properties}

The electrochemical properties of as-prepared MOA and MOV as anode materials of LIBs were investigated in a potential range of $0.01-3.0 \mathrm{~V}$ vs. $\mathrm{Li}^{+} / \mathrm{Li}$. Figure 7 a shows the cyclic voltammetry $(\mathrm{CV})$ curves of $\mathrm{MoO}_{3}$ performed at a scanning rate of $0.01 \mathrm{mV} \mathrm{s}^{-1}$. $\mathrm{MoO}_{3}$ demonstrates four prominent peaks in the first discharge process located at 2.7, 2.28, 0.7 , and $0.3 \mathrm{~V}$. The peaks at 2.7, 2.28, and $0.7 \mathrm{~V}$ appear only in the first discharge cycle and disappear in the subsequent cycles. This feature has been attributed to the intercalation of $\mathrm{Li}$ ions into the interlayer space between $\mathrm{MoO}_{6}$ slabs, which occurs as the $\mathrm{Li}_{x} \mathrm{MoO}_{3}$ phase (see Equation (1)) and causes irreversible structural change to $\mathrm{MoO}_{3}$ in a lithiated amorphous phase [91]. The peak at $0.3 \mathrm{~V}$ originates from a conversion reaction (see Equation (2)) of $\mathrm{Li}_{\mathrm{x}} \mathrm{MoO}_{3}$ to $\mathrm{Mo}^{0}$ and $\mathrm{Li}_{2} \mathrm{O}$ [92]. The shift to a rather low voltage for the peak at $0.3 \mathrm{~V}$ with subsequent cycles may be attributed to a structure evolution. Two broad anodic peaks observed at approximately 1.18 and $1.73 \mathrm{~V}$ correspond to the de-lithiation process and are maintained in the forthcoming cycles. Note that the strong cathodic peak slightly shifts by $0.25 \mathrm{~V}$ after the first cycle. Figure $7 \mathrm{~b}$ displays the galvanostatic charge-discharge profiles of the MOA sample. The upper voltage discharge plateau, observed in the first discharge, disappear in the subsequent cycles and the plateau at approximately $0.3 \mathrm{~V}$ shifts to lower voltage as noticed in $\mathrm{CV}$ results. These electrochemical features are those of the $\mathrm{MoO}_{3}$ phase reported so far [93]. At 1C-rate (current density of $\sim 1.1 \mathrm{~A} \mathrm{~g}^{-1}$ ), the discharge capacity of the $\mathrm{MoO}_{3}$ electrode decreased abruptly from the initial value of 1613 to $330 \mathrm{mAh} \mathrm{g}^{-1}$ over the first 50 cycles and then slightly increased in subsequent discharge-charge cycles at a rate of $0.35 \mathrm{mAh} \mathrm{g}^{-1}$ per cycle, reaching the specific capacity of $435 \mathrm{mAh} \mathrm{g}^{-1}$ after 725 cycles (Figure 7c). The Coulombic efficiency remained almost at 100\% during long-term cycling. The initial large capacity decay revealed the poor electrochemical stability of $\mathrm{MoO}_{3}$ electrode, which was due to the huge volume expansion and/or the structural change during the conversion reaction [91]. The rate capability displayed in Figure 7d for MOA 
showed significant capacity fading upon increasing the loading current. Moreover, after returning to the initial low C-rate (0.1C), the capacity did not return to its initial value and lost more than half of its value.
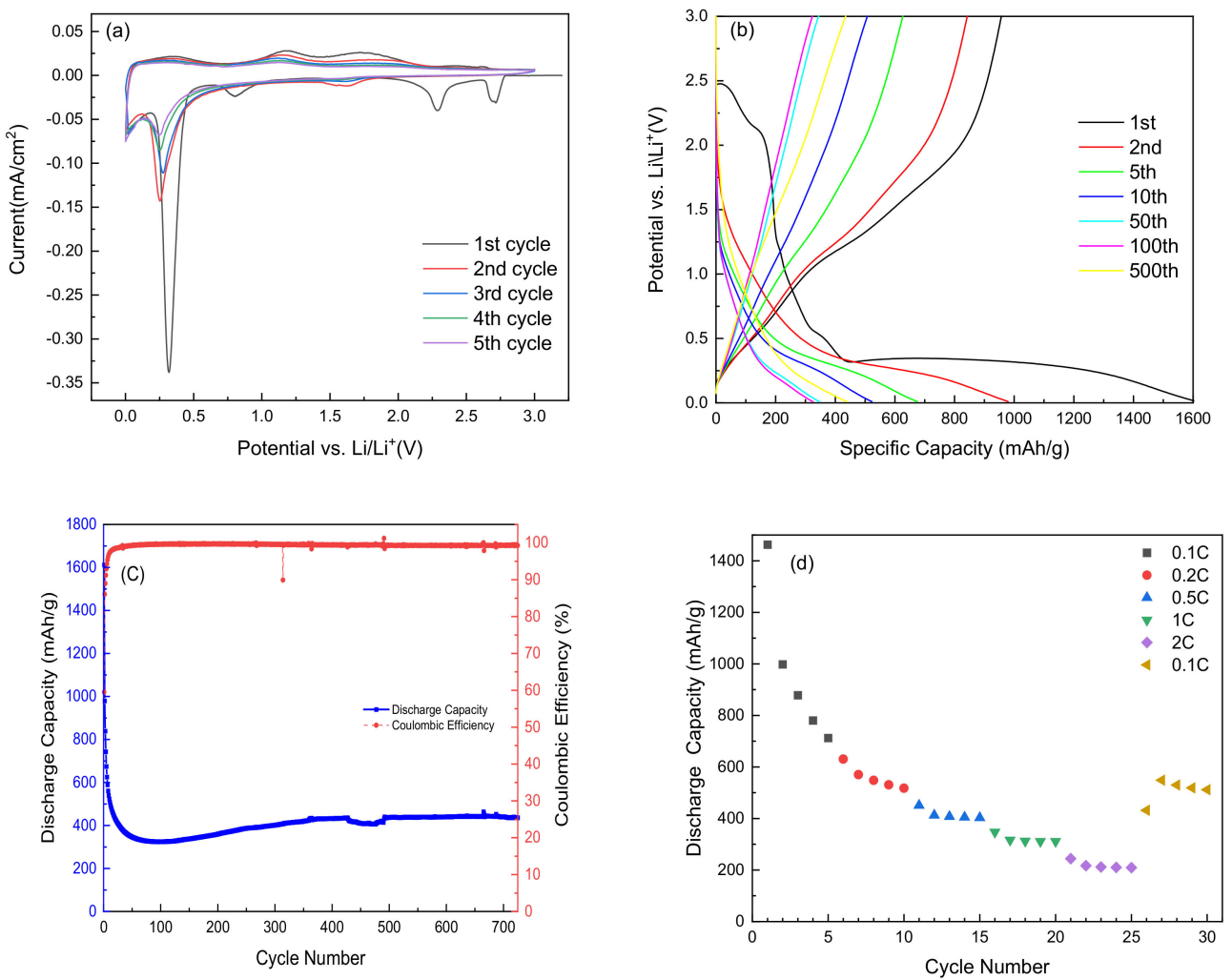

Figure 7. Electrochemical performance of MOA as anode material: (a) five first cyclic voltammograms recorded $0.01 \mathrm{mV} \mathrm{s}^{-1}$ scanning rate, (b) galvanostatic charge/discharge curves carried out at 1C-rate $\left(\sim 1.1 \mathrm{~A} \mathrm{~g} \mathrm{~g}^{-1}\right)$ in the potential window $0.01-3.0 \mathrm{~V}$ vs. $\mathrm{Li}^{+} / \mathrm{Li},(\mathrm{c})$ specific discharge capacity and Coulombic efficiency as a function of cycle numbers performed at a 1C-rate, and (d) rate capability.

Figure 8a shows the first five cyclic voltammograms of the MOV electrode material, which exhibited five cathodic peaks located at 2.03,1.53, 1.25, 0.78, and $0.42 \mathrm{~V} \mathrm{vs.} \mathrm{Li}^{+} / \mathrm{Li}$. Note that the cathodic peaks located at 2.03 and $0.78 \mathrm{~V}$ disappeared starting from the 2nd cycle, and it may be related to the reduction in solution species and formation of a solid electrolyte interphase (SEI) on the anode surface, while the one at $0.42 \mathrm{~V}$ shifted to lower potential. The two strong cathodic peaks at 1.25 and $1.53 \mathrm{~V}$ were maintained in the subsequent cycles with a slight shift toward higher potentials (1.27 and $1.56 \mathrm{~V}$, respectively). This high potential shift makes them close to the two strong anodic peaks at 1.43 and $1.7 \mathrm{~V}$. A decrease in the potential difference $\Delta E$ between the redox peaks started from the $2 \mathrm{nd}$ cycle to 0.16 and $0.14 \mathrm{~V}$ instead of 0.18 and 0.17 observed in the 1 st cycle. In the subsequent cycles, these voltage sets $1.27 / 1.43$ and 1.56/1.7 $\mathrm{V}$ were assigned to the reversible phase transitions (monoclinic-orthorhombic-monoclinic) of partially lithiated $\mathrm{Li}_{x} \mathrm{MoO}_{2}$ during $\mathrm{Li}$ intercalation (discharge) and de-intercalation (charge) processes, which are in a good agreement with previous reports [92-95]. 

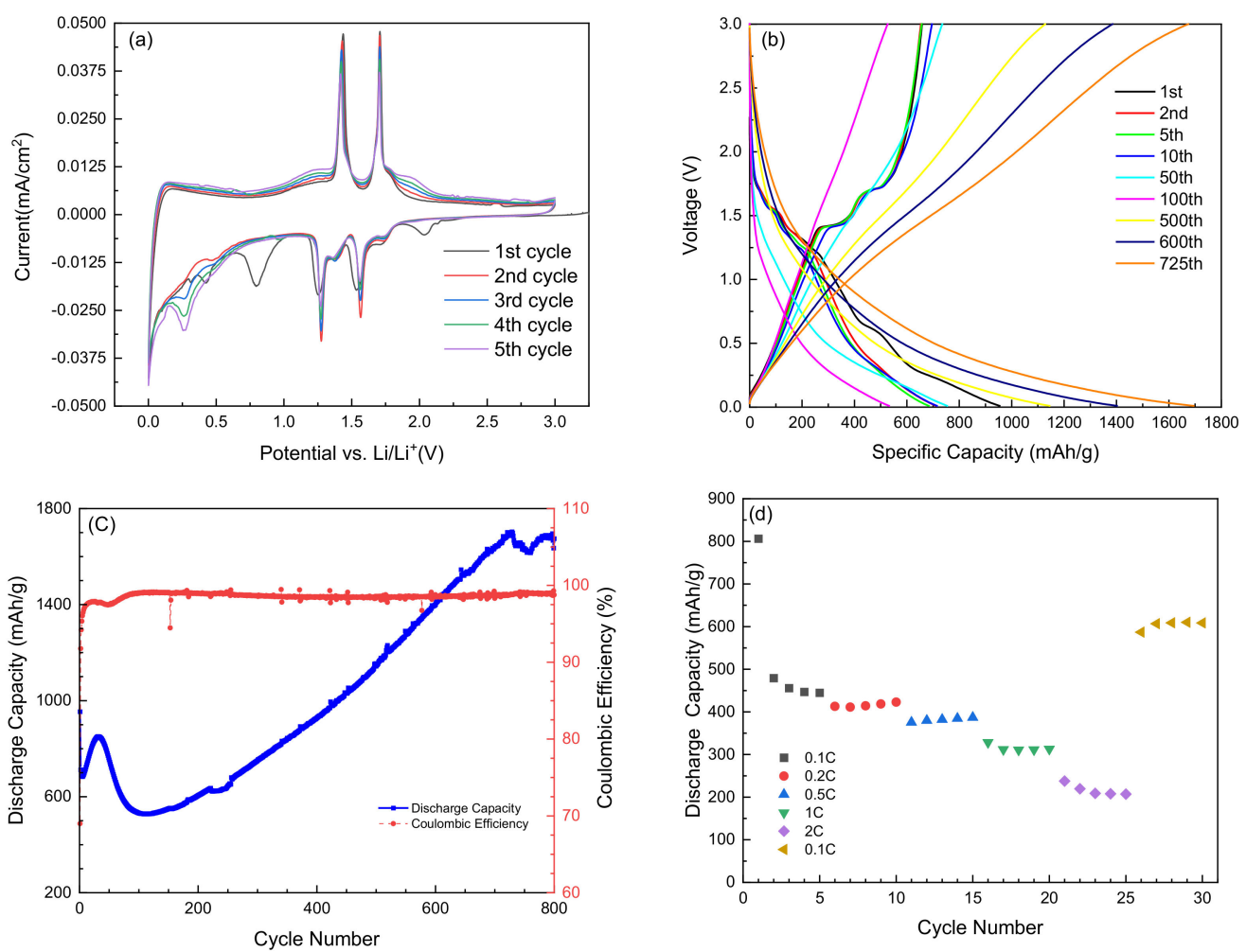

Figure 8. Electrochemical performance of MOV as anode material. (a) First five cyclic voltammograms recorded at scanning rate of $0.01 \mathrm{mV} \mathrm{s}^{-1}$. (b) Galvanostatic charge/discharge curves of $\mathrm{MoO}_{2}$ performed at 1 -rate $\left(\sim 0.86 \mathrm{~A} \mathrm{~g}^{-1}\right)$. (c) Specific discharge capacity and Coulombic efficiency as a function of cycle number performed at 1C-rate. (d) Rate capability.

It is worth noting also that the $\mathrm{CV}$ curves starting from the 2 nd cycle to the 5 th cycle almost overlapped. This demonstrates that the as-prepared material (i.e., the mixture of $\mathrm{MoO}_{2}$ and $\mathrm{Mon}_{\mathrm{n}} \mathrm{O}_{3 \mathrm{n}-1}$ suboxides) had good stability and reversibility for lithium-ion insertion and extraction during the first several cycles. Figure $8 \mathrm{~b}$ illustrates the galvanostatic discharge-charge profiles of the MOV anode material tested at 1C-rate $\left(\sim 0.86 \mathrm{~A} \mathrm{~g}^{-1}\right)$ in a potential window $0.01-3.0 \mathrm{~V}$ vs. $\mathrm{Li}^{+} / \mathrm{Li}$. Two prominent plateaus at 1.25 and $1.53 \mathrm{~V}$ were observed during discharge process besides other small plateaus. The first lithiation mechanism was an insertion-type reaction that took place in the bulk and amorphous $\mathrm{MoO}_{2}$ electrodes with only one-electron reduction as described (see Equation (3)) [46]. The second step was a conversion reaction that gradually resolved $\mathrm{Li}_{x} \mathrm{MoO}_{2}$ as described by Equation (4) [47], showing the formation of metallic $\mathrm{Mo}$ and $\mathrm{Li}_{2} \mathrm{O}$. In the charge curve, two plateaus were evidenced at 1.43 and $1.70 \mathrm{~V}$ and assigned to the deintercalation of $\mathrm{Li}^{+}$ from $\mathrm{Li}_{\mathrm{x}} \mathrm{MoO}_{2}$ framework. The disappearance of small plateaus starting from the 2 nd cycle is related to an irreversible structural change suggesting that part of $\mathrm{Li}^{+}$cannot be extracted during the charge process [69]. Starting from the 2nd cycle, discharge and charge redox plateaus were clearly observed as noticed in the cyclic voltammograms. A voltage upgrading was detected upon cycling the $\mathrm{MoO}_{2}$ phase, which did not exist for $\mathrm{MoO}_{3}$. Figure $8 \mathrm{c}$ exhibits the electrochemical performance of the MOV anode material cycled at 1C-rate. An initial discharge capacity around $900 \mathrm{mAh} \mathrm{g}^{-1}$ was delivered in the 1st cycle, which decreased to $\sim 500 \mathrm{mAh} \mathrm{g}^{-1}$ after 100 cycles and then increased on subsequent cycles reaching a value of $1625 \mathrm{mAh} \mathrm{g}^{-1}$ after 700 cycles. The Coulombic efficiency increased also from $93 \%$ to almost $99.4 \%$ after 100 cycles This better electrochemical behavior of the MOV electrode in comparison with that of MOA is attributed to several factors: (i) the smaller size of the nanoparticles, (ii) the presence of highly conductive suboxide phases, (iii) the higher BET specific surface area, (iv) the high intrinsic electrical conductivity of the $\mathrm{MoO}_{2}$ phase, and (v) the meso-porosity. The importance of cycling at a high C-rate 
was also evidenced in Figure $8 d$, showing the rate capability of the MOV electrode. The rate capability of the MOV electrode is shown in Figure 8d. When the C-rate increased from $0.1 \mathrm{C}$ to $2 \mathrm{C}$, the discharge capacity decreased from approximately $450 \mathrm{mAh} \mathrm{g}^{-1}$ to approximately $200 \mathrm{mAh} \mathrm{g}^{-1}$. However, when the rate returned back to $0.1 \mathrm{C}$ after $2 \mathrm{C}$ testing, the capacity also returned back to approximately $600 \mathrm{mAh} \mathrm{g}^{-1}$, which is slightly higher than the capacity during the initial $0.1 \mathrm{C}$ test. This slight increase was consistent with the capacity change pattern shown in Figure 8c. The capacity slightly increased from the 5 th cycle to about the 50th cycle.

The gradual increase in the discharge capacity and additional capacities beyond the correlating theoretical value upon long-term cycling is worthy to be discussed. This characteristic is common in a large number of conversion reaction metal-oxide anode materials [96-106]. Keppeler and Srinivasan stated that the mechanism leading an experimental capacity larger than the theoretical value remains speculative [98]. The literature reveals a lithium storage capacity higher by $10-100 \%$ at high current densities of $30-2000 \mathrm{~mA} \mathrm{~g}^{-1}$ after being tested beyond 50 cycles [96,97]. Different capacity shapes have been reported that exhibit additional capacity occurrences. Cobalt oxides frequently show a type I (mountshape) capacity profile [99], type II (upward-shape) is observed for additional capacity occurrence for Fe- or Mn-oxide-based electrodes [100], type III (U-shape) is a typical capacity profile found for several cases when the anode material contains Mn or Fe [101], and iron-oxide-based electrodes tend to form a type IV (horizontal-shape) capacity profile [96]. Here, the MOV negative electrode material exhibited a capacity profile type III with a pronounced U-shape. The specific discharge capacity was almost twice the theoretical value after 800 cycles monitored at a high 1C-rate with a Coulombic efficiency, which remained constant at $99.4 \%$. This is in contrast with the type IV profile reported by Shi et al. [102] for the mesoporous $\mathrm{MoO}_{2}$ electrode synthesized at $500{ }^{\circ} \mathrm{C}$ via a nanocasting strategy. However, the self-assembled porous $\mathrm{MoO}_{2}$ /graphene microspheres, fabricated by Palanisamy et al. [103], exhibited a weak U-profile when cycled at a low current rate (C/10). A different capacity profile (upward-shape) was reported by Tang et al. [104] for an $\mathrm{MoO}_{2}-$ graphene nanocomposite electrode cycled at $100 \mathrm{~mA} \mathrm{~g}^{-1}$. Thus, not only the morphology plays an important role in the excess capacity but also the operating mode is modifying the electrochemical performance upon long-term cycling of nanostructured oxides.

After the 100th test, the MOV anode displayed a gradual increase in specific capacity during cycling (Figure 8c). This anomalous behavior can be attributed to: (i) the activation of the porous structure with nano-cavities; the presence of numerous mesopores might be beneficial for the gradual access of the electrolytes in the porous structure of the electrode, and (ii) an additional Li-ion accommodation through reactions with the grain boundary phase in nanostructures; other scenarios associated with additional capacities, such as electrode/electrolyte interphases and electrocatalytic effect of metallic particles, have been identified [98]. The existence of numerous mesopores might be beneficial for more electrolytes accessing in the porous framework of the electrode, which favors the $\mathrm{Li}^{+}$insertion/extraction process. Such a characteristic was evidenced in cobalt-based anodes [105], $\mathrm{MnO} /$ graphene composite [100], and graphene-wrapped $\mathrm{Fe}_{3} \mathrm{O}_{4}$ [106]. In $\mathrm{MnO}_{\mathrm{x}}$ anodes, it might be based on mixed effects such as transition-metal cluster aggregation and formation of defects and deformation [101].

Table 5 summarizes the electrochemical performance of various $\mathrm{MoO}_{2}$ anode materials prepared by various synthetic processes [107-125]. The different strategies demonstrate the ability to mitigate the particle pulverization as a consequence of $\mathrm{Li}$ insertion/extraction and improve the $\mathrm{MoO}_{2}$ electrochemical performance via the fabrication of nanocomposites including carbonaceous materials. The particle size reduction results in the transport path shortening for both ions and electrons, while the carbonaceous matrix maintains high conductivity, large surface area, and chemical stability. The $\mathrm{MoO}_{2}$-based composites studied as lithium battery anodes involve various forms including mesoporous and monolith $\mathrm{MoO}_{2}$; nanostructured powders such as nanowires (NWs), nanospheres (NSs), hollow spheres (HSs), and nanobelts (NBs); $\mathrm{MoO}_{2}$ / carbon materials; various binary composites. Thermo- 
electrochemical activation of $\mathrm{MoO}_{2}$ is also an attractive synthetic approach. A comparison of the electrochemical properties of these anode materials shows that the $\mathrm{MoO}_{2} / \mathrm{Mo}_{\mathrm{n}} \mathrm{O}_{3 \mathrm{n}-1}$ composite prepared by a simple sol-gel technique assisted by a green chelator exhibits the best performance.

Table 5. Electrochemical performance of various $\mathrm{MoO}_{2}$ composites as anode materials for LIBs. The cycle number at which the specific capacity is reported is given in parenthesis.

\begin{tabular}{|c|c|c|c|c|}
\hline Material & Synthesis & $\begin{array}{c}\text { Reversible } \\
\text { Capacity } \\
\left(\mathrm{mAh} \mathrm{g}^{-1}\right)\end{array}$ & $\begin{array}{c}\text { Current } \\
\text { Rate } \\
\left(\mathrm{mA}^{-1}\right)\end{array}$ & Reference \\
\hline Nano $\mathrm{MoO}_{2}$ & rheology & 402 & $100(40)$ & [118] \\
\hline $\mathrm{MoO}_{2} / \mathrm{Mo}_{2} \mathrm{~N}$ & reduction of $\mathrm{MoO}_{3}$ & 815 & $100(150)$ & [119] \\
\hline $\mathrm{MoO}_{2} /$ graphene & chemical vapor deposition & 986 & $50(150)$ & [120] \\
\hline $\mathrm{MoO}_{2} / \mathrm{C}$ & ion exchange & 574 & $100(100)$ & [121] \\
\hline $\mathrm{MoO}_{2} / \mathrm{C}$ & carbothermal reduction & 500 & $100(50)$ & [108] \\
\hline $\mathrm{MoO}_{2} / \mathrm{C}$ hollow spheres & solvothermal & 580 & $200(200)$ & [122] \\
\hline Mesoporous $\mathrm{MoO}_{2}$ & template casting & 750 & $42(30)$ & [103] \\
\hline Activated $\mathrm{MoO}_{2}$ & $\begin{array}{c}\text { thermoelectrochemical } \\
\text { activation }\end{array}$ & 850 & $100(30)$ & [123] \\
\hline $\mathrm{MoO}_{2} \mathrm{HCSMSs}$ & hydrolysis & 420 & $50(30)$ & [124] \\
\hline $\mathrm{W}$-doped $\mathrm{MoO}_{2}$ & nanocasting & 670 & $75(20)$ & [111] \\
\hline $\mathrm{C} / \mathrm{WO}_{\mathrm{x}} / \mathrm{MoO}_{2}$ & hydrothermal & 670 & $90(50)$ & [125] \\
\hline $\mathrm{MoO}_{2} / \mathrm{C} \mathrm{NWs}$ & solvothermal & 500 & $200(20)$ & [109] \\
\hline $\mathrm{C} / \mathrm{MoO}_{2} \mathrm{NSs}$ & hydrothermal+annealing & 675 & $838(30)$ & [113] \\
\hline $\mathrm{MoS}_{2} / \mathrm{MoO}_{2}$ & sulfur assisted & 654 & $500(80)$ & [115] \\
\hline $\mathrm{C} / \mathrm{MoO}_{2} \mathrm{NBs}$ & hydrothermal+annealing & 617 & $100(30)$ & [110] \\
\hline $\mathrm{MoO}_{2}$ monolith & morphosynthesis & 719 & $200(20)$ & [112] \\
\hline$\alpha-\mathrm{MoO}_{3} @ \beta-\mathrm{MnO}_{2}$ & two-step hydrothermal & 286 & $6 C(50)$ & [107] \\
\hline $\mathrm{MoO}_{2} / \mathrm{N}$-doped C NWs & calcination & 700 & $2000(400)$ & [114] \\
\hline C-coated $\mathrm{MoO}_{2}$ & hydrothermal & 312 & $10000(268)$ & [116] \\
\hline $\mathrm{MoO}_{2} /$ flexible C & electrospinning & 451 & $2000(500)$ & [117] \\
\hline $\mathrm{MoO}_{2} / \mathrm{MonO}_{3 \mathrm{n}-1}$ & sol-gel with green chelator & 1600 & $800(800)$ & this work \\
\hline
\end{tabular}

To further investigate the electrochemical kinetics as well as characterize the improved electrochemical properties of MOA and MOV negative electrode materials, EIS measurements were carried out using a fresh cell. Figure 9a shows the Nyquist plots for the MOA and MOV electrodes. The equivalent circuit model (Figure 9b) used to analyze the EIS results is composed of a series of four elements: the cell resistance $R_{\mathrm{s}}$, a resistance in parallel with a constant phase element corresponding to the solid electrolyte interphase (SEI) layer, a second R-CPE parallel component, which figures out the charge transfer process, and finally the diffusion Warburg component $\left(Z_{W}\right)$. All Nyquist plots can be decomposed as follows: (i) the intercept at high frequency with the $Z^{\prime}$-axis is related to the uncompensated ohmic resistance of the cell $\left(R_{\mathrm{S}}\right)$; (ii) in the high-frequency region, the first depressed semicircle is associated with the SEI ( $\left.R_{\mathrm{SEI}}, C P E_{\mathrm{SEI}}\right)$; (iii) a second depressed semicircle in the medium-frequency region is ascribed to the charge transfer impedance and the interfacial capacitance at the electrode/electrolyte interface $\left(R_{\mathrm{ct}}, C P E_{\mathrm{d} 1}\right)$; finally, (iv) in the low-frequency range, the inclined line is ascribed to the $\mathrm{Li}^{+}$-ion diffusion-controlled process characterized by the Warburg impedance. The values of $R_{\mathrm{s}}$ for the two samples are quite small $(\sim 7 \Omega)$ implying a negligible ohmic polarization of the MOA and MOV electrodes. The $R_{\mathrm{ct}}$ value is lower in the MOV material $(211 \Omega)$ compared to the MOA $(272 \Omega)$ electrode. This matches well with the electrochemical performance of MOV mentioned above. This is attributed to the presence of Mo suboxides in MOV electrode (mixture of $\mathrm{MoO}_{2}, \mathrm{o}-\mathrm{Mo}_{4} \mathrm{O}_{11}, \mathrm{~m}-\mathrm{Mo}_{8} \mathrm{O}_{23}$, and o- $\mathrm{Mo}_{9} \mathrm{O}_{26}$ ), which leads to a significant increase in the electronic conductivity as compared to MOA. 

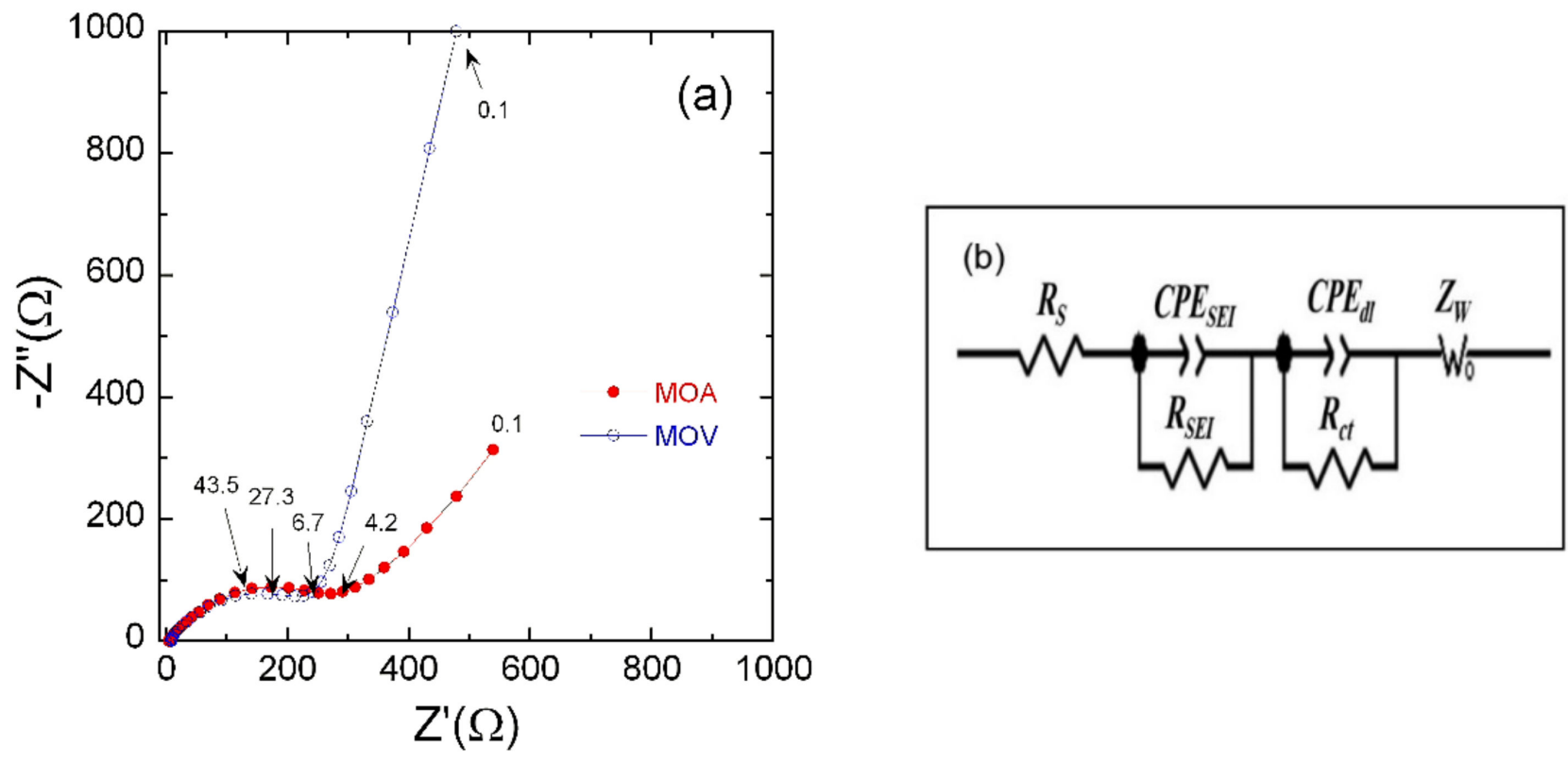

Figure 9. (a) Nyquist plots of fresh cells including the MOA and MOV electrodes. (b) The equivalent circuit model used for EIS data fitting.

More information on the change in the overall cell potential as a function of the depthof-charge (DOD) can be obtained by evaluating the area-specific impedance (ASI expressed in $\Omega \mathrm{cm}^{2}$ ) given by the relation [126,127]:

$$
A S I=A \frac{O C V-V_{\text {cell }}}{I}
$$

where $A$ is the cross-sectional area of the electrode, $\Delta V=O C V-V_{\text {cell }}$ is the potential change during current interruption for $60 \mathrm{~s}$ at each DOD step, and $I$ is the current passing throughout the cell. ASI is affected also by ohmic drop, Li-ion diffusion through the electrolyte and solid-state diffusion within the electrode. This is like EIS measurements without the need to reach the equilibrium. Moreover, ASI could be more representative than data from EIS in terms of evaluation of the total cell resistance. However, ASI results confirmed the features observed by EIS. Figure 10a displays the variation of ASI for the MOA and MOV electrodes for the 1st discharge at 1C-rate. ASI values at $90 \%$ DOD are 22 and $16 \Omega \mathrm{cm}^{2}$ for the MOA and MOV samples, respectively. The curves in Figure 10a indicate that, during battery discharging, the charge-transfer resistance is dependent on DOD. To further verify the effect of ASI on the electrochemical properties of MOA and MOV electrodes, ASI was calculated at various discharge cycles at 20\% and $90 \%$ DOD as shown in Figure 10b. These results show that there were two different behaviors represented by an increase in the ASI values during the first five cycles, followed by a continuous decrease until the 725th cycle. The degree of decay in ASI values was much larger for MOV than for MOA at $20 \%$ DOD. By going to a deep discharge of $90 \%$ DOD, the situation looks rather different. ASI values increased after the 1st cycle then almost stabilizes until the 725th cycle for the MOA electrode. On the contrary, MOV showed smaller ASI values than MOA with a continuous reduction upon cycling upon shallow discharge (20\% DOD). These results show that the lower ASI value was obtained for the MOV sample, and it is beneficial for the long-life cycling behavior. 

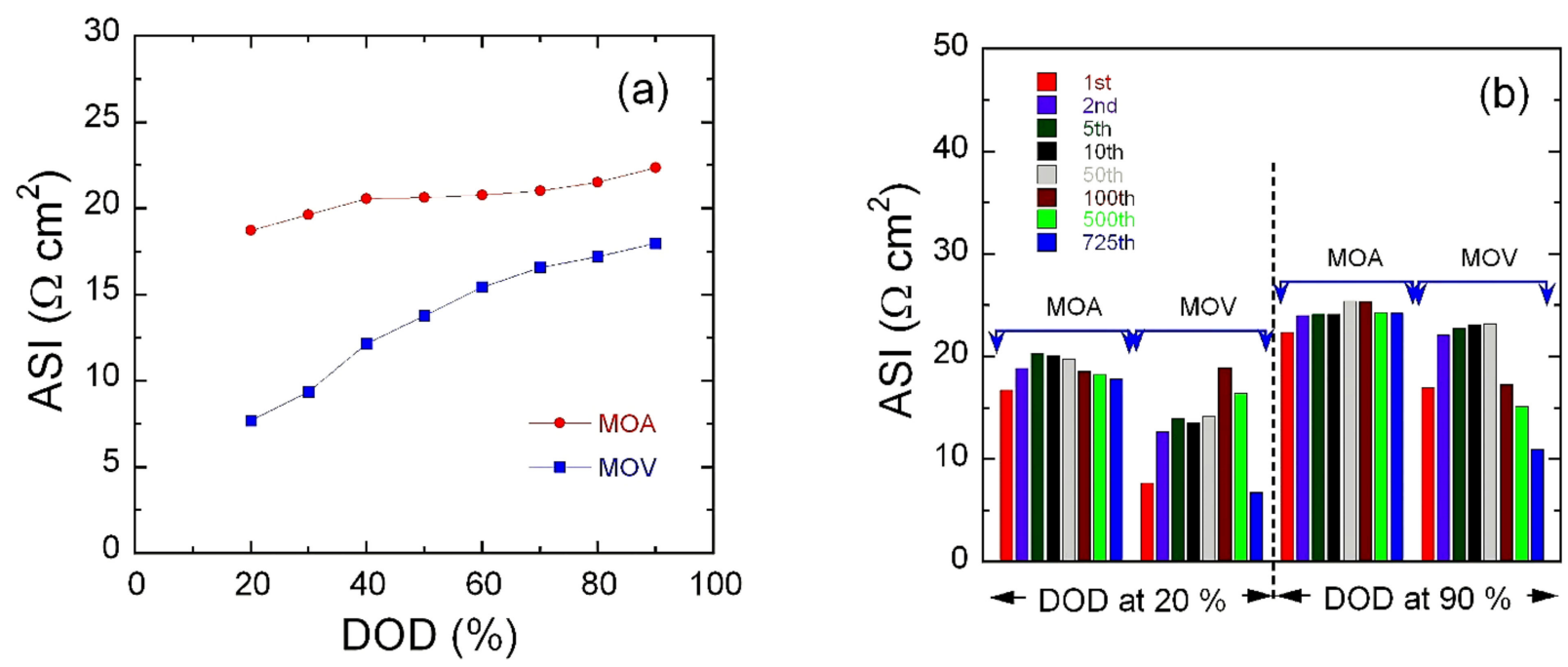

Figure 10. Area specific impedance (ASI) of the MOA and MOV as a function of depth of discharge (DOD) for the 1st discharge (a) and as a function of cycling for the MOA and MOV electrodes at $20 \%$ and $90 \%$ DOD (b).

\section{Conclusions}

This research article sheds light on the promising design strategies of molybdenum oxides for high kinetic energy storage. The green and facile preparation of nanosized molybdenum oxides (i.e., $\mathrm{MoO}_{3}$ and $\mathrm{MoO}_{2}$ ) by thermal decomposition of ammonium molybdate tetra hydrate (i.e., $\left.\left(\mathrm{NH}_{4}\right)_{6} \mathrm{Mo}_{7} \mathrm{O}_{24} \cdot 4 \mathrm{H}_{2} \mathrm{O}\right)$ in air and in an inert atmosphere, respectively, has been demonstrated. The efficiency of the synthetic method is attributed to the use of orange peel extract as a chelator. The as-prepared MOA and MOV materials have the structure of $\mathrm{MoO}_{3}$ and $\mathrm{MoO}_{2}+\mathrm{Mo}_{n} \mathrm{O}_{3 n-1}$ suboxides as estimated from XRD, XPS, and Raman spectroscopy. Thermal analysis emphasized the thermal stable phase of $\mathrm{MoO}_{3}$ up to approximately $800{ }^{\circ} \mathrm{C}$ and the presence of oxygen vacancies in the MOV sample. BET measurements show the mesoporous texture of molybdenum oxides; MOA had a lower specific surface area than MOV due to the easy crystal growth in the $\mathrm{MoO}_{3}$ phase. Electrochemical characterizations showed the outstanding properties in terms of capacity upgrading upon cycling for the MOV negative electrode material, which shows a pronounced U-shape capacity profile when cycled 800 times at 1C-rate. Finally, EIS and ASI experiments confirmed the superiority of the $\mathrm{MOV}$ (mixture of $\mathrm{MoO}_{2}, \mathrm{Mo}_{4} \mathrm{O}_{11}, \mathrm{Mo}_{8} \mathrm{O}_{23}$, and $\mathrm{Mo}_{9} \mathrm{O}_{26}$ phases) over the $\mathrm{MOA}$ (stoichiometric $\mathrm{MoO}_{3}$ insulator) sample as an anode material for Li-ion batteries.

Author Contributions: Conceptualization, L.Z. and A.M.H.; Formal analysis, T.L.; A.E.A.-G., R.S.E.T., H.M.A., H.W., K.C. and A.C.; Investigation: T.L.; A.E.A.-G., R.S.E.-T., H.M.A., H.W., K.C. and A.C.; Writing-original draft preparation, A.M.H., A.E.A.-G., R.S.E.-T., H.W. and A.C.; Writing-review and editing, C.M.J., A.M.H., L.Z., S.Z., H.E.-M. and A.T.; Supervision, L.Z. and A.M.H.; Project administration, L.Z. and A.M.H.; Funding acquisition: L.Z. and A.M.H. All authors have read and agreed to the published version of the manuscript.

Funding: This article was derived from the subject data funded in part by the United States Agency for International Development (USAID) and the National Academy of Sciences (NAS) through Subaward 2000010562. Any opinions, findings, conclusions, or recommendations expressed in this article are those of the authors alone and do not necessarily reflect the views of USAID or NAS.

Institutional Review Board Statement: Not applicable.

Informed Consent Statement: Not applicable.

Data Availability Statement: Data are contained within the article. 


\begin{abstract}
Acknowledgments: The Egyptian authors are grateful for the financial support from the Science, Technology, and Innovation Funding Authority (STIFA, STDF previously) through project number 42691 entitled "Microstructure-Based, Multi-Physics Simulation and Optimization to Improve Battery Performance". Access to XPS at the Nanoscale Characterization Facility at Indiana University was provided by the NSF Award DMR MRI-1126394. S.X.Z. and A.L.C. acknowledge support from the US National Science Foundation through grant number ECCS-1936406 (Raman Studies at Indiana University).
\end{abstract}

Conflicts of Interest: The authors declare no conflict of interest.

\title{
References
}

1. Zhao, X.; Jia, W.; Wu, X.; Lv, Y.; Qiu, J.; Guo, J.; Wang, X.; Jia, D.; Yan, J.; Wu, D. Ultrafine $\mathrm{MoO}_{3}$ anchored in coal-based carbon nanofibers as anode for advanced lithium-ion batteries. Carbon 2020, 156, 445-452. [CrossRef]

2. Jiang, J.; Li, Y.; Liu, J.; Huang, X.; Yuan, C.; Lou, X.W.D. Recent advances in metal oxide-based electrode architecture design for electrochemical energy storage. Adv. Mater. 2012, 24, 5166-5180. [CrossRef] [PubMed]

3. Cheng, X.; Li, Y.; Sang, L.; Ma, J.; Shi, H.; Liu, X.; Lu, J.; Zhang, Y. Boosting the electrochemical performance of $\mathrm{MoO}_{3}$ anode for long-life lithium ion batteries: Dominated by an ultrathin $\mathrm{TiO}_{2}$ passivation layer. Electrochim. Acta 2018, 269, 241-249. [CrossRef]

4. Manthiram, A.; Chemelewski, K.; Lee, E.S. A perspective on the high-voltage $\mathrm{LiMn}_{1.5} \mathrm{Ni}_{0.5} \mathrm{O}_{4}$ spinel cathode for lithium-ion batteries. Energy Environ. Sci. 2014, 7, 1339-1350. [CrossRef]

5. Sun, Y.; Liu, N.; Cui, Y. Promises and challenges of nanomaterials for lithium based rechargeable batteries. Nat. Energy 2016, 1, 16071. [CrossRef]

6. Li, H.; Liu, P.; Zhou, N.; Huang, X.; Wang, H. Electrochemical presodiation promoting lithium storage performance of Mo-based anode materials. Ceram. Int. 2017, 43, 11967-11972. [CrossRef]

7. Goodenough, J.B.; Kim, Y. Challenges for rechargeable batteries. J. Power Sources 2011, 196, 6688-6694. [CrossRef]

8. Hua, R.; Liu, T.; Chen, B.; Cai, R.; Zhou, J. Computational atomic mechanical properties of structure and diffusion in the $\mathrm{MoO}_{3}$ anode materials during lithiation. Mater. Sci. 2018, 145, 8-13.

9. Baldoni, M.; Craco, L.; Seifert, G.; Leoni, S. A two-electron mechanism of lithium insertion into layered $\alpha-\mathrm{MoO}_{3}$ : A DFT and DFT+U study. J. Mater. Chem. A 2013, 1, 1778-1784. [CrossRef]

10. Zhao, K.; Pharr, M.; Wan, Q.; Wang, W.L.; Kaxiras, E.; Vlassak, J.J.; Suo, Z. Concurrent reaction and plasticity during initial lithiation of crystalline silicon in lithium-ion batteries. J. Electrochem. Soc. 2012, 159, A238-A243. [CrossRef]

11. Shang, H.; Zuo, Z.; Li, L.; Wang, F.; Liu, H.; Li, Y. Ultrathin graphdiyne nanosheets grown in situ on copper nanowires and their performance as lithium-ion battery anodes. Angew. Chem. Int. Ed. 2018, 57, 774-778. [CrossRef]

12. Tabassum, H.; Zou, R.; Mahmood, A.; Liang, Z.; Wang, Q.; Zhang, H.; Gao, S.; Qu, C.; Guo, W.; Guo, S. A universal strategy for hollow metal oxide nanoparticles encapsulated into B/N co-doped graphitic nanotubes as high-performance lithium-ion battery anodes. Adv. Mater. 2018, 30, 1705441. [CrossRef]

13. Feng, K.; Li, M.; Liu, W.; Kashkooli, A.G.; Xiao, X.; Cai, M.; Chen, Z. Silicon-based anodes for lithium-ion batteries: From fundamentals to practical applications. Small 2018, 14, 1702737. [CrossRef]

14. Nagaura, T.; Tozawa, K. Lithium ion rechargeable battery. Prog. Batteries Solar Cells 1990, 9, $209-212$.

15. Zhang, W.; Wang, B.; Luo, H.; Jin, F.; Ruan, T.; Wang, D. $\mathrm{MoO}_{2}$ nanobelts modified with an MOF-derived carbon layer for high performance lithium-ion battery anodes. J. Alloys Compd. 2019, 803, 664-670. [CrossRef]

16. Chen, S.; Zhu, J.; Wu, X.; Han, Q.; Wang, X. Graphene oxide- $\mathrm{MnO}_{2}$ nanocomposites for supercapacitors. ACS Nano 2010, 4 , 2822-2830. [CrossRef]

17. Liu, D.; Wang, X.; Tian, W.; Liu, J.; Zhi, C.; He, D.; Bando, Y.; Golberg, D. Ultrathin nanoporous $\mathrm{Fe}_{3} \mathrm{O}_{4}$ carbon nanosheets with enhanced supercapacitor performance. J. Mater. Chem. A 2013, 1, 1952-1955. [CrossRef]

18. Mondal, A.K.; Su, D.; Chen, S.; Xie, X.; Wang, G. Highly porous $\mathrm{NiCo}_{2} \mathrm{O}_{4}$ nanoflakes and nanobelts as anode materials for lithium-ion batteries with excellent rate capability. ACS Appl. Mater. Interfaces 2014, 6, 14827-14835. [CrossRef]

19. Huo, J.; Xue, Y.; Liu, Y.; Ren, Y.; Yue, G. Polyvinyl alcohol-assisted synthesis of porous $\mathrm{MoO}_{2} / \mathrm{C}$ microrods as anodes for lithium-ion batteries. J. Electroanal. Chem. 2020, 857, 113751. [CrossRef]

20. El-Deen, S.S.; Hashem, A.M.; Abdel-Ghany, A.E.; Indris, S.; Ehrenberg, H.; Mauger, A.; Julien, C.M. Anatase TiO 2 nanoparticles for lithium-ion batteries. Ionics 2018, 24, 2925-2934. [CrossRef]

21. Su, Y.; Tong, R.-A.; Zhang, H.; Liang, P.; Wang, C.-A.; Zhong, M. Defocused laser ablation process. A high-efficiency way to fabricate $\mathrm{MoO}_{3}-\mathrm{Mo}$ integrative anode with excellent electrochemical performance for lithium ion batteries. J. Alloys Compd. 2019, 787, 295-300. [CrossRef]

22. Ramana, C.V.; Mauger, A.; Julien, C.M. Growth, characterization and performance of bulk and nanoengineered molybdenum oxides for electrochemical energy storage and conversion. Prog. Cryst. Growth Charact. Mater. 2021, 67, 100533. [CrossRef]

23. Lakshmi-Narayana, A.; Hussain, O.M.; Ramana, C.V.; Camacho-Lopez, M.; Abdel-Ghany, A.; Hashem, A.; Mauger, A.; Julien, C.M. Molybdenum-suboxide thin films as anode layers in planar lithium microbatteries. Electrochem 2020, 1, 160-187. [CrossRef]

24. Julien, C.M.; Mauger, A.; Vijh, A.; Zaghib, K. Lithium Batteries: Science and Technology; Springer: Cham, Switzerland, 2016; pp. 120-124. 
25. Chen, X.; Huang, Y.; Zhang, $\mathrm{K} . \alpha-\mathrm{MoO}_{3}$ nanorods coated with $\mathrm{SnS}_{2}$ nano sheets core-shell composite as high-performance anode materials of lithium ion batteries. Electrochim. Acta 2016, 222, 956-964. [CrossRef]

26. Tang, W.; Peng, C.X.; Nai, C.T.; Su, J.; Liu, Y.P.; Reddy, M.; Lin, M.; Loh, K.P. Ultrahigh capacity due to multi-electron conversion reaction in reduced graphene oxide-wrapped $\mathrm{MoO}_{2}$ porous nanobelts. Small 2015, 11, 2446-2453. [CrossRef]

27. Petnikota, S.; Teo, K.W.; Chen, L.; Sim, A.; Marka, S.K.; Reddy, M.V.; Srikanth, V.V.; Adams, S.; Chowdari, B.V. Exfoliated graphene oxide $/ \mathrm{MoO}_{2}$ composites as anode materials in lithium-ion batteries: An insight into intercalation of Li and conversion mechanism of $\mathrm{MoO}_{2}$. ACS Appl. Mater. Interfaces 2016, 8, 10884-10896. [CrossRef]

28. Zhang, W.; Xing, L.; Chen, J.; Zhou, H.; Liang, S.; Huang, W.; Li, W. Improving the cyclic stability of $\mathrm{MoO}_{2}$ anode for sodium ion batteries via film-forming electrolyte additive. J. Alloys Compd. 2020, 822, 153530. [CrossRef]

29. Ramana, C.V.; Atuchin, V.V. Electrochemical properties of sputter-deposited $\mathrm{MoO}_{3}$ films in lithium microbatteries. J. Vacuum Sci. Technol. A 2012, 30, 04D105. [CrossRef]

30. Li, Y.; Sun, H.; Cheng, X.; Zhang, Y.; Zhao, K. In-situ TEM experiments and first principles studies on the electrochemical and mechanical behaviors of $\alpha-\mathrm{MoO}_{3}$ in Li-ion batteries. Nano Energy 2016, 27, 95-102. [CrossRef]

31. Ma, F.; Yuan, A.; Xu, J.; Hu, P. Porous $\alpha-\mathrm{MoO}_{3} / \mathrm{MWCNT}$ nanocomposite synthesized via a surfactant-assisted solvothermal route as a lithium-ion-battery high-capacity anode material with excellent rate capability and cyclability. ACS Appl. Mater. Interfaces 2015, 7, 15531-15541. [CrossRef]

32. Xia, W.; Xu, F.; Zhu, C.; Xin, H.L.; Xu, Q.; Sun, P.; Sun, L. Probing microstructure and phase evolution of $\alpha$-MoO $\mathrm{M}_{3}$ nanobelts for sodium-ion batteries by in situ transmission electron microscopy. Nano Energy 2016, 27, 447-456. [CrossRef]

33. Zheng, C.; Chen, C.R.; Chen, L.; Wei, M.D. A CMK-5-encapsulated MoSe 2 composite for rechargeable lithium-ion batteries with improved electrochemical performance. J. Mater. Chem. 2017, 5, 19632. [CrossRef]

34. Zeng, L.X.; Huang, X.X.; Chen, X.; Zheng, C.; Liu, R.P.; Chen, G.; Qian, Q.R.; Chen, Q.H.; Wei, M.D. Ethanol thermal reduction synthesis of hierarchical $\mathrm{MoO}_{2}-\mathrm{C}$ hollow spheres with high rate performance for lithium ion batteries. RSC Adv. 2016, 6, 105558. [CrossRef]

35. Zhao, K.; Tritsaris, G.A.; Pharr, M.; Wang, W.L.; Okeke, O.; Suo, Z.; Vlassak, J.J.; Kaxiras, E. Reactive flow in silicon electrodes assisted by the insertion of lithium. Nano Lett. 2012, 12, 4397-4403. [CrossRef]

36. Yang, T.; Yu, X.; Liu, C.; Liang, L.; Wang, W. High-performance lithium storage properties based on molybdenum trioxide nanobelts. Solid State Ion. 2018, 326, 1-4. [CrossRef]

37. Atuchin, V.V.; Gavrilova, T.A.; Grigorieva, T.I.; Kuratieva, N.V.; Okotrub, K.A.; Pervukhina, N.V.; Surovtsev, N.V. Sublimation growth and vibrational microspectrometry of $\alpha-\mathrm{MoO}_{3}$ single crystals. J. Cryst. Growth 2011, 318, 987-990. [CrossRef]

38. Mai, L.Q.; $\mathrm{Hu}$, B.; Chen, W. Lithiated $\mathrm{MoO}_{3}$ nanobelts with greatly improved performance for lithium batteries. Adv. Mater. 2017, 19, 3712-3716. [CrossRef]

39. Xia, W.; Zhang, Q.; Xu, F.; Sun, L. New insights into electrochemical lithiation/delithiation mechanism of $\alpha-\mathrm{MoO}_{3}$ nanobelt by in situ transmission electron microscopy. ACS Appl. Mater. Interfaces 2016, 8, 9170-9177. [CrossRef]

40. Huang, J.; Yan, J.; Li, J.; Cao, L.; Xu, Z.; Wu, J.; Zhou, L.; Luo, Y. Assembled-sheets-like $\mathrm{MoO}_{3}$ anodes with excellent electrochemical performance in Li-ion battery. J. Alloys Compd. 2016, 688, 588-595. [CrossRef]

41. Zhang, P.; Guo, S.; Liu, J.; Zhou, C.; Li, S.; Yang, Y.; Wu, J.; Yu, D.; Chen, L. Highly uniform nitrogen-doped carbon decorated $\mathrm{MoO}_{2}$ nano popcorns as anode for high-performance lithium/sodium-ion storage. J. Colloid Interface Sci. 2020, 563, 318-327. [CrossRef]

42. Wang, W.; Shi, G.; Cai, H.; Zhao, C.; Wu, J.; Yu, Y.; Hu, J.; Fang, Z.; Yan, J.; Liu, B. Yolk-shell structured Mo/MoO 2 composite microspheres function as high-performance anode materials for lithium-ion batteries. J. Alloys Compd. 2019, 792, 191-202. [CrossRef]

43. Zhang, L.; Shen, K.; Jiang, Y.; Song, Y.; Liu, Y.; Yuan, X.; Guo, S. Facile construction of flower-like MoO $\mathrm{ON}_{2}$, P co-doped carbon on carbon cloth as self-standing anode for high-performance sodium ion battery. J. Electroanal. Chem. 2019, 852, 113510. [CrossRef]

44. Ma, J.; Fu, J.; Niu, M.; Quhe, R. $\mathrm{MoO}_{2}$ and graphene heterostructure as promising flexible anodes for lithium-ion batteries. Carbon 2019, 147, 357-363. [CrossRef]

45. Tang, S.; Shen, C.; Ji, W.; Liu, J.; Fichou, D. Template-free synthesis of hierarchical $\mathrm{MoO}_{2}$ multi-shell architectures with improved lithium storage capability. Mater. Res. Bull. 2017, 91, 85-90. [CrossRef]

46. Dahn, J.R.; McKinnon, W. Structure and electrochemistry of $\mathrm{Li}_{\mathrm{x}} \mathrm{MoO}_{2}$. Solid State Ion. 1987, 23, 1-7. [CrossRef]

47. Zhou, L.; Wu, H.B.; Wang, Z.; Lou, X.W. Interconnected $\mathrm{MoO}_{2}$ nanocrystals with carbon nanocoating as high-capacity anode materials for lithium-ion batteries. ACS Appl. Mater. Interfaces 2011, 3, 4853-4857. [CrossRef]

48. Xia, Q.; Zhao, H.L.; Du, Z.H. Facile synthesis of $\mathrm{MoO}_{3} /$ carbon nanobelts as high-performance anode material for lithium ion batteries. Electrochim. Acta 2015, 180, 947-956. [CrossRef]

49. Chen, L.; Jiang, H.; Jiang, H.; Zhang, H.; Guo, S.; Hu, Y.; Li, C. Mo-Based ultra-small nanoparticles on hierarchical carbon nanosheets for superior lithium ion storage and hydrogen generation catalysis. Adv. Energy Mater. 2017, 7, 1602782. [CrossRef]

50. Meduri, P.; Clark, E.; Kim, J.H.; Dayalan, E.; Sumanasekera, G.U.; Sunkara, M.K. $\mathrm{MoO}_{3}$-x nanowire arrays as stable and high capacity anodes for lithium-ion batteries. Nano Lett. 2012, 12, 1784-1788. [CrossRef]

51. Yang, L.; Li, X.; Ouyang, Y.; Gao, Q.; Ouyang, L.; Hu, R.; Liu, J.; Zhu, M. Hierarchical $\mathrm{MoO}_{2} / \mathrm{Mo}_{2} \mathrm{C} / \mathrm{C}$ hybrid nanowires as high-rate and long-life anodes for lithium-ion batteries. ACS Appl. Mater. Interfaces 2016, 8, 19987-19993. [CrossRef] 
52. Zhou, J.; Lin, N.; Wang, L.; Zhang, K.; Zhu, Y.; Qian, Y. Synthesis of hexagonal $\mathrm{MoO}_{3}$ nanorods and a study of their electrochemical performance as anode materials for lithium-ion batteries. J. Mater. Chem. A 2015, 3, 7463-7468. [CrossRef]

53. Xiu, Z.; Kim, D.; Alfaruqi, M.H.; Song, J.; Kim, S.; Duong, P.T.; Mathew, V.; Baboo, J.P.; Kim, J. Ultrafine molybdenum oxycarbide nanoparticles embedded in N-doped carbon as a superior anode material for lithium-ion batteries. J. Alloys Compd. 2017, 696, 143-149. [CrossRef]

54. Zhang, H.-J.; Shu, J.; Wang, K.-X.; Chen, X.-T.; Jiang, Y.-M.; Wei, X.; Chen, J.-S. Lithiation mechanism of hierarchical porous MoO 2 nanotubes fabricated through one-step carbothermal reduction. J. Mater. Chem. 2014, 2, 80-86. [CrossRef]

55. Yang, L.C.; Gao, Q.S.; Zhang, Y.H.; Tang, Y.; Wu, Y.P. Tremella-like molybdenum dioxide consisting of nanosheets as an anode material for lithium-ion batteries. Electrochem. Commun. 2008, 10, 118-122. [CrossRef]

56. Xiao, X.; Peng, Z.; Chen, C.; Zhang, C.; Beidaghi, M.; Yang, Z.; Wu, N.; Huang, Y.; Miao, L.; Gogotsi, Y.; et al. Freestanding $\mathrm{MoO}_{3-x}$ nanobelt/carbon nanotube films for Li-ion intercalation pseudocapacitors. J. Nano Energy 2014, 9, 355-363. [CrossRef]

57. Zhang, P.; Zou, L.; Hu, H.; Wang, M.; Fang, J.; Lai, Y.; Li, J. 3D Hierarchical carbon microflowers decorated with $\mathrm{MoO}_{2}$ nanoparticles for lithium ion batteries. Electrochim. Acta 2017, 250, 219-227. [CrossRef]

58. Nadimicherla, R.; Zha, R.; Wei, L.; Guo, X. Single crystalline flowerlike $\alpha-\mathrm{MoO}_{3}$ nanorods and their application as anode material for lithium-ion batteries. J. Alloys Compd. 2016, 687, 79-86. [CrossRef]

59. Hashem, A.M.; Abuzeid, H.; Kaus, M.; Indris, S.; Ehrenberg, H.; Mauger, A.; Julien, C.M. Green synthesis of nanosized manganese dioxide as positive electrode for lithium-ion batteries using lemon juice and citrus peel. Electrochim. Acta 2018, 262, 74-81. [CrossRef]

60. Abuzeid, H.M.; Hashem, A.M.; Kaus, M.; Knapp, M.; Indris, S.; Ehrenberg, H.; Mauger, A.; Julien, C.M. Electrochemical performance of nanosized $\mathrm{MnO}_{2}$ synthesized by redox route using biological reducing agents. J. Alloys Compd. 2018, 746, 227-237. [CrossRef]

61. Abuzeid, H.M.; Elsherif, S.A.; Abdel-Ghany, N.A.; Hashem, A.M. Facile, cost-effective and eco-friendly green synthesis method of $\mathrm{MnO}_{2}$ as storage electrode materials for supercapacitors. J. Energy Storage 2019, 21, 156-162. [CrossRef]

62. Bampidis, V.A.; Robinson, P.H. Citrus byproducts as ruminant feeds: A review. Anim. Feed Sci. Technol. 2006, 128, 175-217. [CrossRef]

63. Hashem, A.M.; Abuzeid, H.M.; Winter, M.; Li, J.; Julien, C.M. Synthesis of high surface area $\alpha-\mathrm{K}_{\mathrm{y}} \mathrm{MnO}_{2}$ nanoneedles using extract of broccoli as bioactive reducing agent and application in lithium battery. Materials 2020, 13, 1269. [CrossRef] [PubMed]

64. Olabinjo, O.O.; Ogunlowo, A.S.; Ajayi, O.O.; Olalusi, A.P. Analysis of physical and chemical composition of sweet orange (citrus sinensis) peels. Int. J. Environ. Agric. Biotechnol. 2017, 2, 2201-2206. [CrossRef]

65. Kihlborg, L. Least squares refinement of crystal structure of molybdenum trioxide. Ark. Kemi. 1963, $21,357-364$.

66. Hashem, A.M.; Abbas, S.M.; Abdel-Ghany, A.E.; Eid, A.E.; Abdel-Khalek, A.A.; Indris, S.; Ehrenberg, H.; Mauger, A.; Julien, C.M Blend formed by oxygen deficient $\mathrm{MoO}_{3-\delta}$ oxides as lithium-insertion compounds. J. Alloys Compd. 2016, 686, 744-752. [CrossRef]

67. Anderson, S.; Magnelli, A. Structure of $\mathrm{MoO}_{3}$. Acta Chem. Scand. 1950, 4, 793-799.

68. Kihlborg, L. Studies on molybdenum oxides. Acta Chem. Scand. 1959, 13, 954-962. [CrossRef]

69. Magnéli, A. The crystal structures of $\mathrm{Mo}_{9} \mathrm{O}_{26}$ (beta'-molybdenum oxide) and $\mathrm{Mo}_{8} \mathrm{O}_{23}$ (beta-molybdenum oxide). Acta Chem. Scand. 1948, 2, 501-517. [CrossRef]

70. Hashem, A.M.; Abdel-Ghany, A.E.; El-Tawil, R.S.; Indris, S.; Ehrenberg, H.; Mauger, A.; Julien, C.M. Amorphous Mo5 ${ }_{14}{ }^{-}$ type/carbon nano composite with enhanced electrochemical capability for lithium-ion batteries. Nanomaterials 2020, 10, 8 . [CrossRef]

71. Troitskaia, I.B.; Gavrilova, T.A.; Gromilov, S.A.; Sheglov, D.V.; Atuchin, V.V.; Vemuri, R.S.; Ramana, C.V. Growth and structural properties of $\alpha-\mathrm{MoO}_{3}$ (010) microplates with atomically flat surface. Mater. Sci. Eng. B 2010, 174, 159-163. [CrossRef]

72. Williamson, G.K.; Hall, W.H. X-ray line broadening from filed aluminium and wolfram. Acta Metall. 1953, 1, 22-31. [CrossRef]

73. Py, M.; Maschke, K. Intra-and interlayer contributions to the lattice vibrations in $\mathrm{MoO}_{3}$. Physica B + C 1981, 105, 370-374. [CrossRef]

74. Dieterle, M.; Weinberg, G.; Mestl, G. Raman spectroscopy of molybdenum oxides. Part I. Structural characterization of oxygen defects in $\mathrm{MoO}_{3-\mathrm{x}}$ by DR UV/Vis, Raman spectroscopy and X-ray diffraction. Phys. Chem. Chem. Phys. 2002, 4, 812-821. [CrossRef]

75. Py, M.; Schmid, P.E.; Vallin, J. Raman scattering and structural properties of $\mathrm{MoO}_{3}$. Il Nuovo Cimento B 1977, 38, 271-279. [CrossRef]

76. Nazri, G.-A.; Julien, C. Far-infrared and Raman Studies of orthorhombic $\mathrm{MoO}_{3}$ single crystal. Solid State Ion. 1992, 53, $376-382$. [CrossRef]

77. Srivastava, R.; Chase, L.L. Raman spectra of $\mathrm{CrO}_{2}$ and $\mathrm{MoO}_{2}$ single crystals. Solid State Commun. 1972, 11, 349-353. [CrossRef]

78. Spevack, P.A.; Mcintyre, N.S. Thermal reduction of $\mathrm{MoO}_{3}$. J. Phys. Chem. C 1992, 96, 9029-9035. [CrossRef]

79. Dierle, M.; Mestl, G. Raman spectroscopy of molybdenum oxides. Phys. Chem. Chem. Phys. 2002, 4, 822-826. [CrossRef]

80. Navas, I.; Vinodkumar, R.; Lethy, K.J.; Detty, A.P.; Ganesan, V.; Sathe, V.; Mahadevan Pillai, V.P. Growth and characterization of molybdenum oxide nanorods by RF magnetron sputtering and subsequent annealing. J. Phys. D Appl. Phys. 2009, $42,175305$. [CrossRef]

81. Camacho-López, M.A.; Escobar-Alarcón, L.; Picquart, M.; Arroyo, R.; Córdoba, G.; Haro-Poniatowski, E. Micro-Raman study of the $\mathrm{m}-\mathrm{MoO}_{2}$ to $\alpha-\mathrm{MoO}_{3}$ transformation induced by cw-laser irradiation. Opt. Mater. 2011, 33, 480-484. [CrossRef] 
82. Blume, A. Synthese und Strukturelle Untersuchungen von Molybdän-, Vanadium- und Wolframoxiden als Referenzverbindungen für die Heterogene Katalyse. Ph.D. Thesis, Universität Berlin, Berlin, Germany, 2004.

83. Zhao, Y.; Liu, X.; Lei, D.Y.; Chai, Y. Effects of surface roughness of Ag thin films on surface-enhanced Raman spectroscopy of graphene: Spatial nonlocality and physisorption strain. Nanoscale 2014, 6, 1311-1317. [CrossRef]

84. Choi, J.-G.; Thompson, L.T. XPS study of as-prepared and reduced molybdenum oxides. Appl. Surf. Sci. 1996, 93, 143-149. [CrossRef]

85. Novotny, P.; Lamb, H.H. Nanostructured $\mathrm{MoO}_{\mathrm{x}}$ films deposited on c-plane sapphire. J. Vac. Sci. Technol. A 2019, 37, 051504 [CrossRef]

86. Colton, R.J.; Guzman, A.M.; Rabalais, J.W. Electrochromism in some thin-film transition-metal oxides characterized by x-ray electron spectroscopy. J. Appl. Phys. 1978, 49, 409. [CrossRef]

87. Fleisch, T.H.; Mains, G.J. An XPS study of the UV reduction and photochromism of $\mathrm{MoO}_{3}$ and WO . J. Chem. Phys. 1982, 76, 780 [CrossRef]

88. Ramana, C.V.; Atuchin, V.V.; Kesler, V.G.; Kochubey, V.A.; Pokrovsky, L.D.; Shutthanandan, V.; Becker, U.; Ewing, R.C. Growth and surface characterization of sputter-deposited molybdenum oxide thin films. Appl. Surf. Sci. 2007, 253, 5368-5374. [CrossRef]

89. Cimino, A.; DeAngelis, B.A. the application ox X-ray photoelectron spectroscopy to the study of molybdenum oxides and supported molybdenum oxide catalysts. J. Catal. 1975, 36, 11-22. [CrossRef]

90. Thiele, G.; Poston, M.; Brown, R. A Case Study in Sizing Nanoparticles. Micromeritics Instrument Corporation. Available online: http:/ / www.particletesting.com/library (accessed on 1 January 2019).

91. Jung, Y.S.; Lee, S.; Ahn, D.; Dillon, A.C.; Lee, S.-H. Electrochemical reactivity of ball-milled $\mathrm{MoO}_{3-\mathrm{y}}$ as anode materials for lithium-ion batteries. J. Power Sour. 2009, 188, 286-291. [CrossRef]

92. Wu, D.; Shen, R.; Yang, R.; Ji, W.; Jiang, M.; Ding, W.; Peng, L. Mixed molybdenum oxides with superior performances as an advanced anode material for lithium-ion batteries. Sci. Rep. 2017, 7, 44697. [CrossRef]

93. Cho, J.S. Large scale process for low crystalline $\mathrm{MoO}_{3}$-carbon composite microspheres prepared by one-step spray pyrolysis for anodes in lithium-ion batteries. Nanomaterials 2019, 9, 539. [CrossRef]

94. Yang, L.C.; Gao, Q.S.; Tang, Y.; Wu, Y.P.; Holze, R. $\mathrm{MoO}_{2}$ synthesized by reduction of $\mathrm{MoO}_{3}$ with ethanol vapor as an anode material with good rate capability for the lithium-ion battery. J. Power Sour. 2008, 179, 357-360. [CrossRef]

95. Sen, U.K.; Mitra, S. Synthesis of molybdenum oxides and their electrochemical properties against Li. Energy Proc. 2014, 54, 740-747. [CrossRef]

96. Su, L.; Zhong, Y.; Zhou, Z. Role of transition metal nanoparticles in the extra lithium storage capacity of transition metal oxides: A case study of hierarchical core-shell $\mathrm{Fe}_{3} \mathrm{O}_{4} @ \mathrm{C}$ and Fe@C microspheres. J. Mater. Chem. A 2013, 1, 15158-15166. [CrossRef]

97. Zheng, F.; Zhu, D.; Chen, Q. Facile fabrication of porous $\mathrm{Ni}_{\mathrm{x}} \mathrm{Co}_{3-\mathrm{x}} \mathrm{O}_{4}$ nanosheets with enhanced electrochemical performance as anode materials for Li-ion batteries. ACS Appl. Mater. Interfaces 2014, 6, 9256-9264. [CrossRef]

98. Keppeler, M.; Srinivasan, M. Interfacial phenomena/capacities beyond conversion reaction occurring in nano-sized transitionmetal-oxide-based negative electrodes in lithium-ion batteries: A review. ChemElectroChem 2017, 4, 2727-2754. [CrossRef]

99. Grugeon, S.; Laruelle, S.; Dupont, L.; Tarascon, J.M. An uptake on the reactivity of nanoparticles Co-based compounds towards Li. Solid State Sci. 2003, 5, 895-904. [CrossRef]

100. Sun, Y.; Hu, X.; Luo, W.; Xia, F.; Huang, Y. Reconstruction of conformal nanoscale MnO on graphene as a high-capacity and long-life anode material for lithium ion batteries. Adv. Funct. Mater. 2013, 23, 2436-2444. [CrossRef]

101. Guo, J.; Liu, Q.; Wang, C.; Zachariah, M.R. Interdispersed amorphous $\mathrm{MnO}_{\mathrm{x}}$-carbon nanocomposites with superior electrochemical performance as lithium-storage material. Adv. Funct. Mater. 2012, 22, 803-811. [CrossRef]

102. Shi, Y.F.; Guo, B.K.; Corr, S.A.; Shi, Q.H.; Hu, Y.S.; Heier, K.R.; Chen, L.Q.; Seshadri, R.; Stucky, G.D. Ordered mesoporous metallic $\mathrm{MoO}_{2}$ materials with highly reversible lithium storage capacity. Nano Lett. 2009, 9, 4215-4220. [CrossRef]

103. Palanisamy, K.; Kim, Y.; Kim, H.; Kim, J.M.; Yoon, W.-S. Self-assembled porous $\mathrm{MoO}_{2}$ /graphene microspheres towards high performance anodes for lithium ion batteries. J. Power Sour. 2015, 275, 351-361. [CrossRef]

104. Tang, Q.; Shan, Z.; Wang, L.; Qin, X. $\mathrm{MoO}_{2}$-graphene nanocomposite as anode material for lithium-ion batteries. Electrochim. Acta 2012, 79, 148-153. [CrossRef]

105. Mei, W.; Huang, J.; Zhu, L.; Ye, Z.; Mai, Y.; Tu, J. Synthesis of porous rhombus-shaped $\mathrm{Co}_{3} \mathrm{O}_{4}$ nanorod arrays grown directly on a nickel substrate with high electrochemical performance. J. Mater. Chem. 2012, 22, 9315-9321. [CrossRef]

106. Zhou, G.; Wang, D.-W.; Li, F.; Zhang, L.; Li, N.; Wu, Z.-S.; Wen, L.; Lu, G.Q.; Cheng, H.-M. Graphene-wrapped Fe $3 \mathrm{O}_{4}$ anode material with improved reversible capacity and cyclic stability for lithium ion batteries. Chem. Mater. 2010, 22, 5306-5313. [CrossRef]

107. Wang, Q.; Zhang, D.-A.; Wang, Q.; Sun, J.; Xing, L.-L.; Xue, X.-Y. High electrochemical performances of $\alpha-\mathrm{MoO}_{3} @ \mathrm{MnO}_{2}$ core-shell nanorods as lithium-ion battery anodes. Electrochim. Acta 2014, 146, 411-418. [CrossRef]

108. Zeng, L.; Zheng, C.; Deng, C.; Ding, X.; Wei, M. MoO ${ }_{2}$-ordered mesoporous carbon nanocomposite as an anode material for lithium-ion batteries. ACS Appl. Mater. Interfaces 2013, 5, 2182-2187. [CrossRef]

109. Gao, Q.; Yang, L.; Lu, X.; Mao, J.; Zhang, Y.; Wu, Y.; Tang, Y. Synthesis, characterization and lithium-storage performance of $\mathrm{MoO}_{2}$ /carbon hybrid nanowires. J. Mater. Chem. 2010, 20, 2807-2812. [CrossRef]

110. Yang, L.; Liu, L.; Zhu, Y.; Wang, X.; Wu, Y. Preparation of carbon coated $\mathrm{MoO}_{2}$ nanobelts and their high performance as anode materials for lithium ion batteries. J. Mater. Chem. 2012, 22, 13148-13152. [CrossRef] 
111. Fang, X.P.; Guo, B.L.; Shi, Y.F.; Li, B.; Hua, C.X.; Yao, C.H.; Chang, Y.C.; Hu, Y.S.; Wang, Z.X.; Stucky, G.D.; et al. Enhanced Li storage performance of ordered mesoporous $\mathrm{MoO}_{2}$ via tungsten doping. Nanoscale 2012, 4, 1541-1544. [CrossRef]

112. Sun, Y.; Hu, X.; Yu, J.C.; Li, Q.; Luo, W.; Yuan, L.; Zhang, W.; Huang, Y. Morphosynthesis of a hierarchical $\mathrm{MoO}_{2}$ nanoarchitecture as a binder-free anode for lithium-ion batteries. Energy Environ. Sci. 2011, 4, 2870-2877. [CrossRef]

113. Wang, Z.; Chen, J.S.; Zhu, T.; Madhavi, S.; Lou, X.W. One-pot synthesis of uniform carbon-coated $\mathrm{MoO}_{2}$ nanospheres for high-rate reversible lithium storage. Chem. Commun. 2010, 46, 6906-6908. [CrossRef]

114. Yang, L.C.; Sun, W.; Zhong, Z.W.; Liu, J.W.; Gao, Q.S.; Hu, R.Z.; Zhu, M. Hierarchical MoO2 $/$ N-doped carbon heteronanowires with high rate and improved long-term performance for lithium-ion batteries. J. Power Sour. 2016, 306, 78-84. [CrossRef]

115. Xu, Z.; Wang, H.; Li, Z.; Kohandehghan, A.; Ding, J.; Chen, J.; Cui, K.; Mitlin, D. Sulfur refines $\mathrm{MoO}_{2}$ distribution enabling improved lithium ion battery performance. J. Phys. Chem. C 2014, 118, 18387-18396. [CrossRef]

116. Wang, Y.; Huang, Z.; Wang, Y. A new approach to synthesize $\mathrm{MoO}_{2} @ \mathrm{C}$ for lithium ion batteries. J. Mater. Chem. A 2015, 3 , 21314-21320. [CrossRef]

117. Zhang, X.; Gao, M.; Wang, W.; Liu, B.; Li, X. Encapsulating $\mathrm{MoO}_{2}$ nanocrystals into flexible carbon nanofibers via electrospinning for high-performance lithium storage. Polymers 2021, 13, 22. [CrossRef]

118. Liang, Y.; Yang, S.; Yi, Z.; Lei, X.; Sun, J.; Zhou, Y. Low temperature synthesis of a stable $\mathrm{MoO}_{2}$ as suitable anode materials for lithium batteries. Mater. Sci. Eng. B 2005, 121, 152-155. [CrossRef]

119. Liu, J.; Tang, S.; Lu, Y.; Cai, G.; Liang, S.; Wang, W.; Chen, X. Synthesis of $\mathrm{Mo}_{2} \mathrm{~N}$ nanolayer coated $\mathrm{MoO}_{2}$ hollow nanostructures as high-performance anode materials for lithium-ion batteries. Energy Environ. Sci. 2013, 6, 2691-2697. [CrossRef]

120. Huang, Z.X.; Wang, Y.; Zhu, Y.G.; Shi, Y.; Wong, J.I.; Yang, H.Y. 3D graphene supported $\mathrm{MoO}_{2}$ for high performance binder-free lithium ion battery. Nanoscale 2014, 6, 9839-9845. [CrossRef]

121. Che, Y.; Zhu, X.Y.; Li, J.J.; Sun, J.; Liu, Y.Y.; Jin, C.; Dong, C.H. Simple synthesis of $\mathrm{MoO}_{2} /$ carbon aerogel anodes for high performance lithium ion batteries from seaweed biomass. RSC Adv. 2016, 6, 106230-106236. [CrossRef]

122. Wang, Y.W.; Yu, L.; Lou, X.W. Formation of triple-shelled molybdenum-polydopamine hollow spheres and their conversion into $\mathrm{MoO}_{2}$ /carbon composite hollow spheres for lithium-ion batteries. Angew. Chem. Int. Ed. 2016, 55, 14668-14672. [CrossRef]

123. Ku, J.H.; Jung, Y.S.; Lee, K.T.; Kim, C.H.; Oh, S.M. Thermoelectrochemically activated $\mathrm{MoO}_{2}$ powder electrode for lithium secondary batteries. J. Electrochem. Soc. 2009, 156, A688-A693. [CrossRef]

124. Lei, Y.Z.; Hu, J.C.; Liu, H.W.; Li, J.L. Template-free synthesis of hollow core-shell $\mathrm{MoO}_{2}$ microspheres with high lithium-ion storage capacity. Mater. Lett. 2012, 68, 82-85. [CrossRef]

125. Yoon, S.; Manthiram, A. Microwave-hydrothermal synthesis of $\mathrm{W}_{0.4} \mathrm{Mo}_{0.6} \mathrm{O}_{3}$ and carbon-decorated $\mathrm{WO}_{\mathrm{x}}-\mathrm{MoO}_{2}$ nanorod anodes for lithium ion batteries. J. Mater. Chem. 2011, 21, 4082-4085. [CrossRef]

126. Sun, Y.-K.; Myung, S.-T.; Park, B.-C.; Yashiro, H. Improvement of the electrochemical properties of $\mathrm{Li}\left[\mathrm{Ni}_{0.5} \mathrm{Mn}_{0.5}\right] \mathrm{O}_{2}$ by $\mathrm{AlF}_{3}$ coating. J. Electrochem. Soc. 2008, 155, A705-A710. [CrossRef]

127. Amine, K.; Liu, J.; Kang, S.; Belharouak, I.; Hyung, Y.; Vissers, D.; Henriksen, G. Improved lithium manganese oxide spinel/graphite Li-ion cells for high-power applications. J. Power Sour. 2004, 129, 14-19. [CrossRef] 